\title{
Article
}

\section{Institutional complexity and sustainable supply chain management practices}

\author{
Sayed, Maysara, Hendry, Linda C. and Bell, Marta Zorzini \\ Available at http://clok.uclan.ac.uk/28020/ \\ Sayed, Maysara, Hendry, Linda C. and Bell, Marta Zorzini (2017) Institutional \\ complexity and sustainable supply chain management practices. Supply \\ Chain Management: An International Journal, 22 (6). pp. 542-563.
}

It is advisable to refer to the publisher's version if you intend to cite from the work. http://dx.doi.org/10.1108/SCM-10-2016-0365

For more information about UCLan's research in this area go to http://www.uclan.ac.uk/researchgroups/ and search for < name of research Group>.

For information about Research generally at UCLan please go to http://www.uclan.ac.uk/research/

All outputs in CLoK are protected by Intellectual Property Rights law, including Copyright law. Copyright, IPR and Moral Rights for the works on this site are retained by the individual authors and/or other copyright owners. Terms and conditions for use of this material are defined in the policies page.

\section{CLoK}

Central Lancashire online Knowledge www.clok.uclan.ac.uk

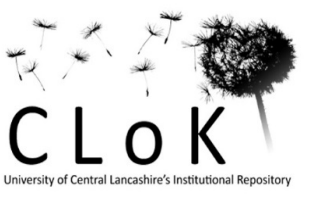




\title{
Institutional Complexity and Sustainable Supply Chain Management Practices
}

\author{
Author 1: $\quad$ Maysara Sayed \\ University/Institution: University of Edinburgh Business School \\ Town/City: $\quad$ Edinburgh \\ Country: UK
}

Author 2: $\quad$ Professor Linda C. Hendry

Department: $\quad$ Department of Management Science

University/Institution: Lancaster University Management School

Town/City: Lancaster

Country: UK

Author 3: $\quad$ Dr Marta Zorzini Bell

Department: $\quad$ University of Liverpool Management School

University/Institution: University of Liverpool

Town/City: $\quad$ Liverpool

Country: UK

[Accepted for publication with 'Supply Chain Management: An International Journal' on September $\left.5^{\text {th }}, 2017\right]$ 


\section{Structured Abstract}

Purpose: To empirically investigate the impact of: institutional pressures; institutional logics; and institutional complexity; on Sustainable Supply Chain Management (SSCM) practices across mixed public and private sector supply chains.

Design/methodology/approach: Multi-case study data was collected from three tiers of food and catering supply chains: the customer/consumer tier; focal public sector UK Universities; and private sector suppliers / contractors.

Findings: The findings indicate that: normative and mimetic pressures are more prevalent in focal Universities, compared to suppliers; there is typically no single dominant logic across these supply chains; and the multiplicity of institutional logics (e.g., sustainability logic versus financial logic) increases institutional complexity. Therefore, in the atypical case of homogeneity in terms of institutional pressures and logics, e.g. with a dominant sustainability logic throughout the supply chain, radical change in SSCM practices is facilitated. In contrast, in the more typical case when there is heterogeneity, with competing logics at different supply chain tiers, this limits SSCM to more incremental changes in practices.

Research limitations/implications: This study is limited to three tiers of the food and catering supply chains of UK Universities.

Practical implications: To aid in the successful implementation of SSCM, this study suggests a need for managers to develop an initial understanding of the prevailing institutional logics and pressures at different tiers of the supply chain.

Social implications: A number of the SSCM practices studied address social sustainability.

Originality/value: No previous studies have empirically investigated the impact of institutional complexity in the context of SSCM practices across supply chains, involving both mixed public and private sector organisations.

Keywords: Sustainable Supply Chain Management; Institutional Theory; Institutional Pressures; Institutional Logics; Institutional Complexity; Multi-Case

\section{Introduction}

Sustainability has become a key aspect of supply chain management as part of the increasing corporate social and environmental responsibilities of companies (Sarkis et al., 2010). Thus the concept of Sustainable Supply Chain Management (SSCM) has emerged, as defined by Carter \& Rogers (2008) as "the strategic, transparent integration and achievement of an 
organisation's social, environmental, and economic goals in the systemic coordination of key inter-organisational business processes for improving the long-term economic performance of the individual company and its supply chains" (p. 368). Therefore, it can be argued that one of the main features of SSCM is that it is based on the inter-organisational field that affects and is affected by the interaction and integration between different organisations across the supply chain (Svensson, 2007; Sarkis et al., 2011; Miemczyk et al., 2012; Grosvold et al., 2014). It is argued here that a greater understanding of these interactions between multiple tiers of supply chain actors will increase the effective implementation of SSCM practices. This paper aims to develop this understanding by using an institutional theory lens, including the constructs of institutional pressures, logics and complexity (DiMaggio and Powell, 1983, Greenwood et al., 2011).

In practical terms, the paper aims to aid supply chain actors who are championing the use of SSCM practices throughout their supply chains by providing a better appreciation of the prevailing institutional pressures and logics affecting the willingness of their customers and/or suppliers to implement changes. Therefore, by equipping supply chain actors with a better understanding of institutional complexity at the supply chain level, it is anticipated that they will be better able to influence change towards their SSCM goals. Such changes may focus on one particular type of sustainability (environmental, social or economic sustainability) or may attempt to address two or three aspects of sustainability simultaneously. For example, Zorzini et al. (2015) consider the social dimension alone and in their review of the literature indicate that this includes factors affecting worker rights and safety throughout the supply chain. In contrast, local sourcing is an example of a practice that has been argued by authors such as Oglethorpe \& Heron (2013) and Czinkota et al. (2014) to address all three dimensions of sustainability, as it can: address environmental issues by reducing food miles; address social issues by providing employment for the local community; and address economic issues by retaining revenues within the region. This paper adopts a broad view of SSCM, as defined by Carter \& Rogers (2008) above and seeks to understand how institutional theory can aid in the implementation of a variety of types of SSCM practices.

From an institutional theory perspective, few studies have explicitly studied the impact of institutional logics on SSCM at the supply chain level (Miemczyk et al., 2012). A key exception is the work by Glover et al. (2014), who provide evidence for institutional isomorphism and the presence of homogeneity in the form of a dominant financial logic in multiple supply chain tiers. This prior study also illustrates how different organizations may 
experience common institutional pressures, in terms of sustainability development, that the supply chain needs to respond to across its tiers. However, Glover at al. (2014) focus on a purely commercial supply chain, in which it could be argued that there is a high chance of homogeneity. In contrast, heterogeneity assumptions have been proposed by Greenwood et al. (2011), who suggest that a multiplicity of institutional logics can lead to institutional complexity, and call for more empirical studies to contribute to the elaboration and further understanding of these phenomena. Yet, to-date, there are no published studies that discuss institutional complexity in the context of SSCM practices in diverse supply chains including public and private sector organisations, and in which a multiplicity of institutional logics might be more likely to occur. Thus, this paper adds to the prior literature by studying a diverse supply chain, providing important empirical evidence for the concept of institutional complexity, including the investigation of the relationship between logics and pressures as well as how these evolve over time. The resulting research questions are as follows:

RQ1: How do institutional pressures and logics vary across mixed public and private sector supply chains, thereby affecting SSCM practices?

RQ2: How does a multiplicity of institutional logics and organizational attributes shape institutional complexity, and thereby impact changes in SSCM practices within mixed public and private sector supply chains?

To answer these questions, a multi-case study approach has been adopted to investigate the implementation of SSCM in the food and catering supply chains of UK Higher Education (HE) institutions. This context was selected as it includes both public and private sector organisations (universities and food suppliers respectively) with varying degrees of saliency to the general public and media. Before further justifying the methodology and presenting the findings, this paper first explains the theoretical background and reviews the extant literature.

\section{Institutional Theory and the extant SSCM literature}

Institutional theory provides a theoretical lens that aids in understanding the influences that promote similarity of the organisations' structures and gives legitimacy to organisational practices within an organisational field (Meyer and Rowan, 1977; DiMaggio and Powell, 1983). DiMaggio and Powell (1983) defined the organizational field as "those organizations that, in the aggregate, constitute a recognized area of institutional life: key suppliers, resource and product consumers, regulatory agencies, and other organizations that produce similar services or products" (p. 148). However, Wooten and Hoffman (2008) argue that the 
conceptualization of an organizational field is evolving "where previous definitions of the field centred around organizations with a common technology or market (i.e. SIC classification), the field began to be seen as forming around the issues that became important to the interests and objectives of a specific collective of organizations" (p. 134). Therefore, it can be argued that the supply chain can be considered to be an inter-organizational field, containing different organizations, irrespective of whether they are in the same industry or have common technology, but working together and depending on each other to continue in their businesses and achieve their objectives. This connectedness makes them face the same institutional pressures that need to be responded to not only on the organizational level in the same tiers, but across the whole supply chain. These institutional pressures are discussed below.

\subsection{Institutional Pressures}

According to institutional theory, the institutional isomorphism process is a means of gaining legitimacy within the organisational field, as a response to three different types of institutional pressures: coercive, normative and mimetic pressures (DiMaggio and Powell, 1983; March and Olsen, 1984). The coercive pressures are exerted from formal and informal forces that are practiced upon the organizations from other powerful organizations or entities upon which the organizations depend (DiMaggio and Powell, 1983). Within the sustainability context, these pressures can be in the form of sustainability rules and regulations exerted by government, requiring the implementation of specific sustainability practices (Zhu and Sarkis, 2007; Wu et al., 2013). Also they can be exerted by powerful customers that put pressure upon supplier organisations to comply with specific sustainability requirements (Tate et al., 2011; Moxham and Kauppi, 2014). Normative pressures stem from professionalism and associated networking (DiMaggio and Powell, 1983). So organisations are confronted with normative pressures to be perceived as legitimate among their peers within their professional community (Bhakoo and Choi, 2013). Thus within a sustainability context, these pressures can be exerted by sustainable trading alliances and associations and the desire of organisations to be associated with them (Tate et al., 2011). Also normative pressures can stem from the social obligation that organisations feel towards their societies and communities to be seen to be doing the right thing (March and Olsen, 1989). Mimetic pressures stem from uncertainty and results in organisations attempting to model themselves on other successful organisations (DiMaggio and Powell, 1983). The competition between 
organisations in terms of sustainability practices are often sources of mimetic pressures in this context (Zhu and Sarkis, 2007; Wu et al., 2012).

Several studies have examined the existence of these pressures and their influence on organizations to adopt SSCM practices (e.g., Zhu and Sarkis, 2007; Sarkis et al., 2010; Sarkis et al, 2011; Tate et al., 2011; Wu et al., 2012; Varsei et al., 2014; Moxham and Kauppi, 2014; Grosvold et al, 2014). Some have argued that these institutional pressures could have a significant influence (Zhu and Sarkis, 2007; Tate et al., 2011). For example, Zhu and Sarkis (2007) found that coercive and normative pressures influenced Chinese manufacturers to adopt SSCM practices such as eco-design and green purchasing leading to improved environmental performance. However, most prior studies concentrate on institutional pressures affecting organisations within one tier of the supply chain (focal companies or suppliers) with very few examples that have tried to examine multiple tiers of the supply chain in this context (e.g., Glover et al., 2014).

Furthermore, it can be argued that the influence of institutional pressures in the domain of SSCM could be contextual, with varying impacts of the three types of pressures (Clemens and Douglas, 2006; Sarkis et al., 2010; Wu et al., 2012). For example, Clemens and Douglas (2006) found that the relationship between the external institutional pressures for the adoption of voluntary green initiatives is weaker or non-existent when the firms have internal superior resources (e.g., extensive environmental documentation and effective environmental training) associated with their environmental strategies. Similarly, Sarkis et al. (2010) found in their studies of automotive companies that an effective response to institutional pressures needs the development of intangible knowledge capacities; whereas without training to acquire these capacities, the institutional pressures may go unheeded. In addition, the significance of particular pressures can be affected by other factors associated with the implementation of SSCM, such as organisational support, social capital and government involvement (Wu et al., 2012). Thus, it can be argued that the response to institutional pressures regarding SSCM practices can vary according to different factors that are related to the organisations themselves, which could include the readiness of organisations and how they perceive or interpret these pressures. This supports the idea of heterogeneity as an alternative to isomorphism in the implementation of SSCM practices (Hoffman, 2001), which is also in need of further study on multiple supply chain levels rather than only the one tier level (Sarkis et al., 2011).

\subsection{Institutional Logics and Heterogeneity}


Heterogeneity has begun to be acknowledged by institutional theorists as a result of different responses from organisations to the institutional pressures (Greenwood and Hinings, 1996; Hoffman, 2001; Bunduchi et al., 2008; Greenwood et al., 2010; Bhakoo and Choi, 2013). The prior literature uses the concept of 'institutional logics' to understand the reasons for this heterogeneity (Thornton and Ocasio, 2008). Thornton (2004) defined institutional logics as "assumptions and values, usually implicit, about how to interpret organizational reality, what constitutes appropriate behaviour, and how to succeed" (p. 70). Therefore, "rather than positing homogeneity and isomorphism in organizational fields, the institutional logics approach views any context as potentially influenced by contending logics of different societal sectors" (Thornton and Ocasio, 2008).

Since the term was introduced by Alford and Friedland (1985), an increasing number of studies have discussed institutional logics in different contexts (e.g., Thornton and Ocasio, 1999; Thornton and Ocasio, 2008; Besharov and Smith, 2014). The previous studies have shown the possible dynamics of institutional logics in terms of their evolution over time (e.g., Thornton and Ocasio, 1999) and also in terms of the contradictions and competition between the different logics at any one point in time (Greenwood et al., 2011; Besharov and Smith, 2014). For example, Thornton and Ocasio (1999) investigated shifting logics in the Higher Education Publishing Industry from an editorial logic to a market logic. Greenwood et al. (2010) investigated how multiple logics, such as regional state logic, family logic and market logic, require different responses thereby creating complex institutional contexts for organisations. Similarly, in the context of SSCM, it can be argued that the need to encourage organisations to think more sustainably is creating a new logic that tries to replace, compete with or complement other dominant logics such as market and financial logics. However, to date the institutional logic concept is not often included in the SSCM literature that uses institutional theory. Key examples of exceptions to this are discussed below.

Within the institutional logics literature, there are very few studies that have investigated supply chain management in general (e.g. Gawer and Phillips, 2013) or SSCM in particular (e.g., Heiskanen, 2002; Glover et al., 2014). For example, Gawer and Phillips (2013) studied the dramatic shift in institutional logic of the Intel Corporation's supply chain, within the computer industry, from traditional supply chain logic dominated by computer assemblers to a new platform logic. Within the context of SSCM, Heiskanen (2002) has studied the life cycle approach (LCA) as an emerging institutional logic that influences the way environmental problems, and responsibility for them, are conceptualized using data from wholesale-retail purchasers. On a supply chain level, Glover et al. (2014) studied institutional 
logic across the dairy supply chain exploring different stakeholder views including producers, primary producer suppliers, transporters, processors, retailers, and consumers of dairy products. They found that financial logic (reducing cost and maximising profit) is dominant throughout this commercial supply chain which suggests difficulties and challenges in complementing this logic with sustainability practices. More studies are needed at the supply chain level to further understand and investigate the role of current institutional logics in facilitating or hindering the implementation of sustainability. In particular, more diverse supply chains need to be studied rather than simple commercial supply chains - for example, including actors in different industries (including manufacturing and services industries), which have different purposes (for profit and non-profit companies).

\subsection{Institutional Complexity}

Finally, as well as considering institutional pressures, and institutional logics, there is also a need to consider 'institutional complexity' (Greenwood et al., 2011; Greenwood et al., 2010; Besharov and Smith, 2014). Greenwood et al. (2011) argue that organizations face institutional complexity as a result of having multiple, and conflicting, institutional logics. They suggest that this complexity creates challenges and tensions for two reasons in particular. Firstly, it is not fixed, but it is dynamically shaped through the continuous evolving of the institutional logics. Secondly, the position of the organization within the field (e.g., central or peripheral) determines its saliency to institutional complexity; and the organization's characteristics (e.g., structure, ownership, governance and identity) determine its sensitivity to certain logics. Therefore, organizations could have different responses to the institutional complexity within the organizational field. To the best of our knowledge, no prior studies have discussed institutional complexity in the context of SSCM.

In conclusion, most of the prior SSCM literature that has used institutional theory focused on the influence of institutional pressures, without utilising the constructs of institutional logics and institutional complexity. Therefore, the previous research does not develop a sufficiently deep understanding of how organisations perceive and interact with these pressures and what causes heterogeneity or isomorphism thereby influencing SSCM practices. Furthermore, most prior studies concentrate, predominantly, on the firm level (focal companies or suppliers) or buyer-supplier dyadic relationships, with very few examples that examine sustainability at three or more supply chain tiers. This paper addresses 
these gaps by considering the impact of institutional pressures, logics and complexity on SSCM at multiple tiers of the supply chain.

\section{Research Framework and Methodology}

Given the dearth of prior research that has considered institutional complexity in the SSCM context, exploratory research is needed to enable theory building. Therefore, a multi-case study approach was adopted, as this is argued to be an appropriate method for exploratory research that aims to be theory-generating and/or theory-elaborating (Voss, 2009; Ketokivi \& Choi, 2014), further, it also facilitates the collection of rich and profound data to better understand the issues being explored (Eisenhardt \& Graebner, 2007; Yin, 2009). An abductive approach (Saunders et al., 2016) was adopted for the research, using some prior constructs developed from the extant literature on institutional theory, but also allowing other issues to emerge inductively from the data, as further discussed in the data analysis section below. In choosing the cases, three tiers have been included to provide a supply chain perspective: the focal organisations' tier; first supplier tier; and the customer tier. This study has dual units of analysis, where: the organisations within each tier are considered to be the unit of analysis for identifying the prevailing institutional pressures and institutional logics; while the supply chain as an inter-organisational field is the unit of analysis for understanding institutional complexity.

\subsection{Case Selection and Data Collection}

Food and catering supply chains of 5 UK HE institutions have been selected for this research as these supply chains contain both public sector universities and private sector suppliers. Whilst there is also a research gap to study institutional complexity in a SSCM context in all types of supply chains, this diverse supply chain was selected as it was felt that it would be more likely to bring light to conflicting pressures/logics given potential differences in organisational objectives. Thus this context is argued to have greater potential for developing understanding of the implications of a multiplicity of institutional logics within the interorganisational field. The selection of the cases follows theoretical sampling principles, whereby each additional case either predicts similar results (a literal replication); or produces contrary results but for predictable reasons (a theoretical replication) (Eisenhardt, 1989, Voss, 2009, Yin, 2009). For example, 5 public sector UK universities have been chosen for literal replication; whilst the study includes a mixture of small local suppliers; larger national 
suppliers and catering contractors for theoretical replication. For the customer tier, this research focused on students as they represent the majority of food consumers. By interviewing student representatives within the students' union, this study aims to understand the perspective of both: students who are actively engaged with sustainability initiatives; and the vast majority of students who are not members of active sustainability groups. Finally, two food purchasing consortiums in the HE sector have been interviewed to provide a broader perspective given their work with many different universities.

The data collection process was completed in three phases; with preliminary data analysis conducted after each of the first two phases (Miles et al., 2014, Voss, 2009). Data collection ceased when it was felt that the saturation level had been achieved, i.e., when no more significantly new data was being collected (Eisenhardt, 1989). In total, 33 semistructured face-to-face interviews were conducted. Table 1 provides details of each interviewee and organisation included in the study, including the length of each interview; and Figure 1 illustrates the relationship between the supply chain actors.

\section{[Take in Table 1 and Figure 1]}

For each tier of the supply chains under this study, the interviewees have been chosen carefully to be the most knowledgeable individuals who can talk about food and catering sustainability initiatives/practices in their organisations/entities. For the focal companies (universities) tier, the interviewees have been chosen mainly from procurement departments who deals with the food supply chain and its sustainability initiatives/practices (as in the cases: FHE1, FHE2, FHE3, FHE4 and FHE5). For local and small suppliers, managing directors were interviewed where possible as they are most familiar with their small businesses (as in the cases: LS1, LS2, LS3, LS5). Where this was not possible for some local suppliers and both of the big national suppliers, sales representatives were interviewed given that they manage the relationship with the focal organisations selected. These interviewees were both familiar with their customers' requirements and expectations towards sustainability issues and at the same time they are quite familiar with sustainability practices within their own businesses given their role in 'selling' this competence to the customers (as in the cases: LS4, LS6, LS7, NS1, NS). Finally, for the customer tier, student union representative(s) were interviewed in each university as they were felt to be able to best reflect the overall perspective of students, given their experience in working with different types of students. This was deemed better than interviewing only a few student consumers and having an incomplete picture about the overall students' perspective. Therefore student representatives employed in the student unions of the five universities were chosen, who are specifically 
responsible for sustainability projects/initiatives with the students. These interviewees provided evidence of both: the student union's perspective, as an entity; and the student consumers' perspectives (as in the cases $\mathrm{C} 1, \mathrm{C} 2, \mathrm{C} 3, \mathrm{C} 4, \mathrm{C} 5$ ).

In order to ensure the research quality, construct validity, external validity, internal validity and reliability measurements as relevant to a case study approach have been fulfilled (Yin, 2009). To ensure construct validity, other secondary data and documents have also been collected for triangulation purposes with the interview data. Secondary data sources include: the organisations websites; published sustainability reports; and documents provided by the interviewees such as suppliers' assessments questionnaires and protocols, sustainability policies and action plans. In addition, at least two respondents have been interviewed in each focal university. To ensure external validity, multiple cases have been chosen by replication logic, as discussed above. To ensure internal validity, pattern matching of the data has been used through cross-case analysis. To ensure reliability, the same rigorous process of data collection has been used with all cases and respondents. This process consists of four stages. Firstly, a set of questions was prepared for each group of interviewees - the questions used for the focal organisations are included in the Appendix in Table A1, which also illustrates how the questions are linked to the main constructs under investigation. Secondly, the interview questions were sent to the relevant interviewees in advance; along with a summary of the research objectives and a consent form - clarifying the rights of both participants and researchers. Thirdly, the interviews were recorded and transcribed verbatim, leading to a total of 298 pages of interview data. Finally, the transcripts were sent to the interviewees for validation and authenticity checking.

\subsection{Data Analysis}

Data coding and analysis were guided by the three main constructs of institutional theory used in this study, as defined in Table 2 below and summarised as: institutional pressures (identifying normative, coercive and mimetic pressures as well as evaluating their strength); institutional logics (identifying the main institutional logics embedded in the data and evaluating their strength) and institutional complexity (through identifying the impact of the multiplicity of institutional pressures and logics; and the homogeneity and heterogeneity process). The codes used are presented in Table 3, and include both the constructs identified in the extant institutional theory literature discussed above and themes identified from the data which are used as sub-codes. Thus the first order codes and the second order codes associated with the institutional pressures are all from the extant literature, whilst the 
remaining second order codes and all of the third order codes emerge from the data. In terms of institutional complexity, the codes demonstrate the manner in which it was qualitatively assessed by first identifying conflicting logics i.e. between sustainability logic and financial logic or between sustainability logic and time logic. Having established the presence of conflicting logics, the challenges associated with a particular conflict were then assessed, followed by the resultant strategies to overcome those challenges and the outcomes in terms of the impact on changes towards SSCM goals.

Given that some of the codes emerged from the data, the full set of codes was circulated between two of the researchers for confirmation, with any initial disagreements resolved through discussion. In addition, the relative strengths of the prevailing pressures and logics were independently assessed by two of the researchers before discussion to agree minor discrepancies in judgement. Due to the supply chain perspective used, the within-case and cross-case analysis process has been structured as suggested by Bhakoo and Choi (2013). This process starts with traditional within-case analysis, considering each case in each tier in turn; and then searches for patterns at two levels of cross-case analysis: within-tier analysis; and cross-tier analysis. Data analysis and coding were facilitated by the NVIVO software.

[Take in Tables 2 and 3]

\section{Findings: Single Tier Analysis of Institutional Pressures and Logics}

The findings for the single tier analysis (referred to as within-tier analysis by Bhakoo and Choi, 2013) include the institutional pressures and institutional logics at each level of the supply chain studied, as discussed below. These findings are summarised in Tables 4 and 5, with Table 6 providing definitions of the institutional logics identified in the data. Whilst Tables 4 and 5 only provide sample quotes for some of the organisations included in the study, this evidence is confirmed by the other organisations unless otherwise indicated in the right hand columns of Tables 4 and 5, and in the discussion below.

[Take in Tables 4, 5 and 6]

\subsection{Institutional Pressures: Focal Universities}

As shown in Table 4, the strong pressures impacting the SSCM practices of the focal universities are normative and mimetic. In terms of normative pressures, they stem from: 'ethical obligations' that the universities feel towards society due to a perceived expectation to be good role models; or from membership of purchasing consortiums/alliances, which 
influences appropriate norms for the procurement profession in HE institutions. In terms of mimetic pressures, the universities model themselves on best practice in the field to gain a high rank in the universities' sustainability league tables (i.e., the Green League Table). As confirmed by interviewees from all the universities under study, the competition in the Green League Table has become a strong pressure.

However, the findings have not suggested strong governmental coercive pressures upon universities regarding their food and catering SSCM practices. This may be because UK universities are independent legal entities and are only partially funded by government. It may also be due to the university policies and practices being much more advanced than the minimum regulations implemented by government, "I don't think that government tells us what we do, I think in some ways certainly university catering is ahead of the game when it comes to sustainability" (FHE2-I1). In addition, there is conflicting evidence in terms of the coercive pressures received from students, with some interviewees claiming that sustainability practices are driven by students: "We are much more engaged with it because students are engaged with it” (FHE2-I1), whilst others stated: “... it always looks like they are very pro sustainability. But in actuality, I haven't seen that here ..." (FHE5-I2). Given that the former interviewees tended to be referring to sustainability activist groups rather than the student body as a whole, it is concluded that this pressure is not strong. Therefore, overall, it is concluded that the coercive pressures are relatively weak for this tier in the supply chain, and that normative and mimetic pressures are the main drivers behind SSCM food and catering initiatives.

\subsection{Institutional Pressures: Suppliers}

For all three supplier types included in this study (local small suppliers; catering contractors; and national suppliers), the data suggests that the coercive pressures from their customers are the main pressures behind the implementation of sustainability practices, as evidenced by the sample quotes in Table 4. For the local suppliers, these coercive pressures stem from their dependency on these big customers, given that they represent a large proportion of the suppliers' business. This has been confirmed by 6 out of 7 of the local small suppliers in this study. For example, LS3 explained: “our most recent initiative that really we joined and it's really a process of jumping through the hoops would be the Red Tractor initiative, so we've signed up for that and I would say that was largely driven by the requirements of the University, the University is the only person that we deal with that has that requirement and we've been able to get Red Tractor accreditation, so we've invested a lot of time and money 
in achieving that". Thus our data suggests that local small suppliers are mainly driven by the pressures of their customers, especially bigger customers, which require sustainability accreditations.

The exception is LS5, which is more driven by normative pressures such as concerns about the environment and professionalism identity. This supplier is a co-operative of local and organic suppliers that aims to prove the commercial viability of sustainable food, thereby enhancing the concept of organic and local food. So from the outset, its mission was sustainability related rather than being a purely commercial venture. Also in certain industries, such as the coffee industry, there are norms and trends that are felt as normative pressures (e.g. fair trade and rainforest alliance coffee). For example, as explained by LS6 (i.e., coffee supplier) "they [our main wholesalers] must follow the trend in the market ... that is how the market has changed and that's how it has developed ... probably 10 years ago it was quite driving towards Fairtrade and ethically traded, that now is rolled into quality, and that seems to be the market norm now".

With regards to both catering contractors, the coercive pressures that stem from the contract agreements are strong. These contracts stipulate penalties, ultimately including the right of the university to terminate the contract, if the catering contractors fail to achieve their agreed sustainability targets. However, before signing these contracts, mimetic pressures play a greater role especially with big contractors. These mimetic pressures stem from the competition between contractors to win university contracts, as explained for example by Con1 "I think the reason for that is that some clients in universities, schools and colleges won't even think to do any business with anybody unless they have the accreditations and they have the potential to do things correctly. ... we want to be the best at the end of the day". With regards to national suppliers, the findings suggest that there is no direct significant coercive influence from the universities. Instead, mimetic pressures are prevailing, which stem from competition for higher market shares. As explained by NS1-I1 "We want to be the best and most forward thinking above everybody else ... for me when I am going out and trying to gain new business that is a key thing that I discuss, it's not about price, it's about services and our green accreditation ...".

Interestingly, the findings suggest that governmental coercive pressures are not perceived as strong pressures behind the implementation of sustainability practices and initiatives within the supplier tier. Although there is some legislation related to energy, waste, recycling and packaging, pressure from this legislation is not perceived to be as strong as the 
other pressures discussed above. Con1 explained the reason for this: "In actuality there is no pressure from the government. My personal view is that the government aren't particularly interested in improving sustainability, but they wanna tick the box, so it is more of a tick box exercise”. Furthermore, other suppliers, especially local small suppliers, do not perceive any pressures from government, as mentioned for example by LS1 "There are no current pressures from government. The council inspectors that are employed by the government visit the business once a month on average and only inspect aspects related to quality. So the pressures are very little".

\subsection{Institutional Pressures: Customers}

In terms of institutional pressures at the customer tier of the supply chain, the findings suggest that there are no strong normative, mimetic or coercive pressures that are relevant to this group. For example, as stated by $\mathrm{C} 1$, "Not really, other than enthusiasm, there is no real pressure out there; I think the pressure is from us upon the university to change a few things". It can therefore be concluded that the Student Union groups are self-motivated groups, who exert pressure to act in a sustainable manner on other members of the supply chain. However, the evidence suggests that there is a medium level of normative pressure for the Student Union, for example as stated by C4: "And then there is a social norm for it. For example if something is perceived as the standard and if the conscience is raised about these issues, people start shifting their behaviours".

\subsection{Institutional Logics: Focal Universities}

In terms of universities, the data suggests that sustainability logic has become stronger than purely financial logic in recent years. This is evidenced, for example, through claims that there has been a recent shift in emphasis from costs to sustainability in the universities' strategies, for example, FHE4-I1 stated: "before, our emphasis was more about the cost than concern about where they get their food from, but in the last five or six years the emphasis has been changed and sustainability is much stronger". These strategies are implemented by giving procurement specialists more freedom to consider sustainable sourcing options without necessarily using price as the key decision-making criterion, as explained by several interviewees including FHE2-I2, FHE4-I1, FHE1-I2. For example: "For sure cost is there in the sustainable procurement but it is not always the final marker, we look at everything else where it is important to be sustainable. So yes if it costs more, it costs more" (FHE4-I1). This has also been confirmed by some suppliers (e.g., LS6, LS4, LS3, and LS1). For example, the 
manager of LS6 stated that "I have dealt with other customers, which are much more pricedriven, whereas the University seems to be more on quality along with sustainability".

However, financial logic still overrides sustainability logic in some instances, as the University needs to find some way to offset the cost of more expensive sustainable sourcing options in order to remain commercially viable: "Cost is considered one of the main challenges because everything in the budget is very tight, this is something that we can afford, but generally I have to offset it somewhere else, or try and find a way that makes it work cheaper" (FHE2-I2). If offsetting the costs is not possible, then the principle of customer affordability becomes important, as explained by FHE2-I1 “we don't do it at any cost because we can't ... whilst catering is subsidised to a certain degree, it would be wrong if everything was organic at the expense of us having to charge students a lot of money for whatever they are buying, so yes it should be a balance really".

\subsection{Institutional Logics: Suppliers}

With the majority of suppliers under study, the data suggests that financial logic dominates their thinking regarding sustainability practices. The business or commercial motive behind this financial logic takes different forms such as responding to customers' requirements as explained by LS3 “The University is a very important part of our business and really one of the drivers of our business at the moment ... we may not have pursued the Red Tractor if it wasn't driven by the customer really". Another business-related motive is to reduce costs, such as by saving energy, recycling and reducing waste, as explained by LS7 "the reason why we would look to save energy would be ... primarily to save money, because it is like any business, it is very good to save the environment but if you end up paying too much without income, it is difficult for us". Therefore, several suppliers indicated that they will only implement sustainability practices if this leads to increased profits or reduced costs, as for example mentioned by LS2: “well, it's [sustainability] always there, it's always relevant, but ultimately it has to make business sense for what we are doing. If it is making business sense then we will pursue it, ... if it costs money to do it or there is no return on our investment, there's no sense in looking at it". This was confirmed by the majority of suppliers as further evidenced in Table 5.

In comparison to the strong evidence for financial logic amongst suppliers, the evidence for sustainability logic is weak overall, as only one of the suppliers studied indicated that this is their dominant logic, LS5 - the co-operative of local and organic suppliers: "I think sustainability is extremely important because the objective of the organisation is to prove that 
there is a suitable food system that can be localised and is not supposed to be based on Brazil". In this exception, the Triple Bottom Line (TBL) is crucial, given their aim to prove that social and environmental sustainability is commercially viable.

\subsection{Institutional Logics: Customers}

In terms of the sustainability groups in the students' unions, it is not surprising that the findings confirm that sustainability logic dominants their thinking, given that sustainability is their raison d'etre. It can therefore be argued that this sustainability logic is much stronger in these customer representative groups than in the university overall. As for example stated by $\mathrm{C} 1$ "So the main goal of (our group) is to make the campus more green and get students and staff practically involved in that as well". Thus, they are mainly funded and evaluated according to their sustainability agenda, which is not the case for any other tier of the supply chain being studied.

For the student body as a group of consumers, the data suggests that financial and time logic are dominant in their thinking and interaction with sustainability initiatives, as illustrated in Table 5. Due to their restricted budgets, a main concern for students is how much certain initiatives or practices will cost them: "I think in general most of the students would be quite price aware, so they would care about price. I think that is important. Some of the people think that the canteen is too expensive for example and even other markets around the University they like them but they can't go there because it is too expensive. So I think price is important" (C2). The other important logic that dominants students thinking is time, as there are many things that compete for their time (e.g., lectures, course-work, exams and socialising): "Students are focusing on getting through their studies, probably have jobs and have their social life. So it's been a challenge to fully engage with the campus community and students' population and not just talk to the people who are already sensitised and educated about sustainability" (C1). Whilst there are some enthusiastic students, the majority are not strongly influenced by sustainability logic: "there is always a keen group of students around who want to grow their own food, but then we have to think about how to reach out to students who don't want to get their fingers dirty down at the allotment ..."(C1).

\section{Findings: Supply Chain Analysis of Complexity}

As discussed above and summarised in Table 7 the data suggests that the dominant institutional pressures differ according to supply chain tier and that there are multiple logics 
within the supply chain under study, with overriding/dominant logics for each tier. Further evidence of the existence of conflicting logics is also provided in the sample quotes in Table 8 , which lists the main sources of conflicting logics in the left hand column and sample quotes to provide evidence for these sources of conflict in the right hand column. This multiplicity of logics and their different degrees of compatibility with each other and with SSCM as an institutional demand increases the degree of institutional complexity in the supply chain (Greenwood et al., 2011). This complexity results in challenges in both the upstream and downstream parts of the supply chain which need a response by supply chain actors. The data suggests that the universities are the most salient actors in terms of responding to these challenges due to their position as focal organisations within the supply chain and their characteristics, (including size, governance, purpose, salience to the media and general public). This saliency puts more pressure and responsibility on the university to solve and respond to the challenges caused by complexity in both the upstream and downstream supply chain. Thus the universities can be argued to be "pressure/challenge absorbers" within the supply chain under study. This saliency towards institutional complexity is conceptually illustrated in Figure 2 before being explained further below.

[Take in Tables 7 and 8, and Figure 2]

Figure 2 shows the three main actors of the supply chain under study, Universities (as focal organisations), suppliers and customers (student consumers and students union), as well as the dominant logic for each of them, in the middle three rectangles. As discussed above, institutional complexity occurs due to the interaction between multiple competing institutional logics, which are illustrated in Figure 2 by the two star bursts within the supply chain. The two middle arrows represent the institutional pressures that are practiced by customers on the universities and also the pressures the universities have on suppliers. Although, the direction of pressures are towards the upstream supply chain, these pressures come back in the form of challenges from both directions towards the universities as they are the most salient supply chain actor to the institutional complexity. The two arrows at the top represent this. The top funnel indicates how the universities absorb these challenges from both sides of the supply chain, the customers and the suppliers. The bottom funnel explains how the universities try to deal with these challenges by introducing different relieving strategies, reactive and proactive strategies, to diffuse sustainability along the supply chain. Evidence from the data to support this illustration is further discussed below by first focusing on upstream institutional complexity, followed by a discussion of the downstream. 


\subsection{Upstream Institutional Complexity}

In terms of upstream institutional complexity, the challenges stem from the conflict between the university's sustainability pressures and the financial logic of suppliers. They may be expressed in the form of deliberate resistance, which tends to occur more with catering contractors, national and international suppliers; or undeliberate resistance, which is generally the case with the small and medium suppliers due to their low sustainability capabilities.

As an example of the findings in support of deliberate resistance, FHE5-I2 argued that: "with all the catering companies that I have worked with, at the end of the day they look after their own pocket and their own company and all of that". Thus there can be cost-related resistance from contractors to implement additional sustainability requirements introduced by the university after signing the contract. Similarly, for the larger national suppliers, the data suggests that financial logic takes priority when it conflicts with sustainability practices; and in this case the university has very little influence especially when it deals with suppliers individually (outside the purchasing consortium's framework). This is explained for example by FHE3-I2: “... with the larger national suppliers we have not got that influence as much. I think that's a pro again for working with local rather than national suppliers". Thus, the university has to find a way to overcome this type of resistance when working with contractors and national/international suppliers.

In contrast, an example of undeliberate resistance from the smaller local suppliers can stem from a lack of sustainability documentation as needed for auditing processes / sustainability certificates, as explained for example by FHE1-I2: "we had one who was very slow at coming through with the information as they didn't have it to hand". In addition, it may be that having the sustainability documentation does not make financial sense to these suppliers. As LS3, which sources from a local farm, stated: "we can trace that chain and that's really good in terms of food miles because the farm is six miles away, the slaughterhouse is 2 miles away and then back to the shop, so it's really nice. Interestingly it's not Red Tractor because this farm is assured but the slaughterhouse isn't because it is small so they don't pay and don't need to and it's not part of its commercial DNA ..., so the Red Tractor route breaks down although it's a wonderful, traceable and provable small supply chain". However, a key sustainability initiative evidenced in the findings is the use of local small and medium suppliers, as confirmed by all five universities and both purchasing consortiums. Therefore, the university has to face these challenges (in addition to other general challenges of local sourcing such as availability, volume, higher prices and supplier 
delivery capabilities) if they want to continue with this initiative and encourage their suppliers to diffuse sustainability initiatives across the upstream part of the supply chain.

As a result of the universities' saliency in responding to the challenges caused by institutional complexity in the upstream supply chain, and their perceived responsibility for the implementation of SSCM, the universities use different strategies to alleviate these pressures/challenges, referred to hereafter as "pressure/challenge relieving strategies". These can be categorised into two main groups: reactive strategies and proactive strategies.

In terms of reactive strategies, the evidence suggests that these tend to take the form of trade-offs between one sustainability initiative against another. For example, the university could trade-off ensuring that all suppliers have sustainability certificates and good systems for sustainability documentation to continue to use small local suppliers. The opposite may also occur, when Universities depend more on national and multinational suppliers than local suppliers to gain the associated advantages. In the latter case the universities may then try to gain the best of both worlds by influencing its national suppliers to source from local suppliers further upstream. For example, FHE5 has attempted to influence its contractor Con2 to use more local suppliers, but the evidence suggests that Con2 continues to mostly source from global suppliers as it is a multinational company that buys in bulk as a group.

In terms of proactive strategies, two key examples are: working collaboratively with suppliers; and joining consortiums/alliances. The former can help to reduce the conflict between the financial logic of suppliers and the university sustainability requirements. As explained for example by FHE5-I2 "when you are trying to achieve all these things, it is always important to ensure that they [caterers] fully appreciate the benefits of doing these things. ... that it is gonna hopefully increase their business". The latter can reduce the challenges for individual universities and increase collective influence upon suppliers. As explained for example by FHE2-I1: "using the purchasing consortium is a great help, because it's for them to ensure that our suppliers are delivering in the best way possible, whether that's in the type of vehicles that they use or the food that they are supplying, .... The purchasing consortium has also engaged with MSC (Marine Stewardship Council) to allow us to get the accreditation much more easily".

\subsection{Downstream Institutional Complexity}

Within the downstream supply chain, the institutional complexity is mainly caused by the tension between university logics (sustainability logic and financial logic) and student logics (strong sustainability logic for the SU and financial/time logics for student consumers). Thus 
there can be barriers for SU sustainability initiatives, which could be financial: "so whenever we get [financial] pressure, it often back-fires straight to the university, because they are our funders, we have dabbled with trying to self-fund in the past, but that's not something that I am particularly interested in any more, it is not really gonna work" (C1); logistical barriers such as space: "[there are] conflicting priorities on space" $(\mathrm{C} 1)$; or even bureaucracy barriers: "the challenges are that everything takes a very long time in the university to happen, massive bureaucracy to even suggest something should be changed" (C2). Thus, whilst ultimately there is a considerable degree of compatibility between the university's \& SU's sustainability logic, there are also challenges that the University has responsibility to solve.

In terms of student consumers, the main challenges are affordability and engagement, due to the conflict between student financial and time logics and the university's sustainability logic. The affordability challenge has been confirmed by students' representatives: "I think the concern for me right now is that students will always come back to the economic argument and say well, I would love to buy more local and sustainable food but it is more expensive, or I would love to buy more organic food and support organic farms but it is more expensive. So I think the challenge for the university is actually making the local and sustainable food options ... more affordable” (C1). Similarly, the evidence suggests there is a need for Universities to encourage students to engage with sustainability initiatives due to conflicting time logic: "there are a lot of competing demands on the time of students ... to have vast numbers of students coming down to the eco hub, giving up even just two hours once a year, is quite a tall order these days." (C1). Thus there is a challenge for the university to address these two issues, as it experiences this complexity more than other supply chain parties.

As for the upstream supply chain, the response to these downstream institutional complexity challenges can be reactive or proactive. In terms of reactive strategies, the university can transfer the challenge back to the customers. For example: "local companies tend to charge more, and we do try to negotiate on price, asking for a reduction ... if they can, good. If they can't, then sometimes we just accept it and pass the price onto the customer" (FHE1-I2). However the data suggest that the universities don't often use this type of strategy. There is more evidence that the University uses proactive strategies to overcome these challenges. These strategies are mainly focused on more open communication channels with the SU sustainability groups to encourage early engagement of student consumers in sustainability initiatives to attain higher levels of understanding and commitment towards 
these initiatives. For example: "One of the projects that we are working on at the moment is to remove Styrofoam containers from campus use and looking at a reusable sandwich box and a token scheme to implement that and in the next few weeks or months we will engage with different elements. You know, we've got meetings with the student union ..., so almost it will become a campaign by the students so the students are forcing the change, ... and the campaign gathers momentum, ... which is good for us" (FHE3-I1).

\subsection{The Impact of Institutional Complexity on SSCM}

The findings suggest that the presence of institutional complexity in the supply chain can have a direct impact on the types of SSCM practices that can be implemented. In particular, the evidence illustrates that competing multiple logics at different tiers of the supply chain can limit progress towards SSCM to incremental change, with radical change only occurring where there is an absence of institutional complexity. Here we define incremental change as a minor change that impacts only a part of the supply chain; whilst a radical change leads to a truly sustainable solution that impacts many different supply chain tiers, and may even have a positive spill over effect for other supply chains. To illustrate this, two examples of radical change and one example of incremental change from the data are described in turn below.

In terms of radical change, a key example is the case of the 'LS5-FHE2-C2-Student Consumers' supply chain, in which the use of this particular supplier is in itself argued to be a radical change in SSCM practices. As explained above, LS5 is a local organic growers' cooperative that aims to advocate local organic produce through proving its commercial viability. LS5, as an exception from the majority of suppliers in this study, shares the same perception of pressures (normative pressures) and embedded logic (sustainability logic) with FHE2 (the focal organisation). As stated by LS5: "FHE2 is a participant member in the co-op and the principle purchaser sits on the committee of the co-op ... so they [FHE2] share the same agenda ... and the communication is exceptionally good and it happens on a very regular scheduled basis as well as informally ...". Taking a buyer's perspective, FHE2-I2 stated: "our biggest sustainability initiative is working with LS5, they grow local organic food and everything is within 50 miles from [our city] ... we buy as much produce as we can from them". This initiative also is highly compatible with the agenda of the SU of FHE2, as expressed by C2: “we've also got a food co-op [LS5] that does a lot of work around here and brings fresh food and vegetables and sells veg boxes locally sourced", thereby impacting student consumption This encouraged the SU of FHE2 to put more pressure on the university to imitate this initiative in other areas of procurement, as explained by $\mathrm{C} 2$ : "So this year we 
managed to get the university to start using the workers' rights consortium when they are getting their garments, so all the way up the supply chain of the University garments, they are now fully tested that they have good working conditions and they pay a fair rate". Thus, as can be seen from this example, radical change is taking place throughout this supply chain, not just within one tier of the chain, and this influence extends to other supply chains including garment procurement.

Another example of radical change on the supply chain level is the case of 'Con1FHE4-C4-Student Consumers' in the area of local sourcing. As stated by Con1, a British (national) contractor: "the core values of our business are that: we buy local; we buy seasonal; and we buy British produce to support the local economy and farmers". Thus, there is compatibility between pressures perceived and the embedded logic between Con 1 and its university customers especially in the area of local sourcing. This has encouraged Con 1 to develop its supply chain structure from a centralisation structure to a decentralisation structure, thereby also impacting many other supply chains in which Con1 is involved. As explained by Con1: "this decentralised structure allows you to use small suppliers which allow you to have less road miles; it allows you to support the local economy, support local infrastructure and all of that good sustainability stuff'. Thus this decentralisation structure provides a competitive advantage, as it has around 2500 small local suppliers who are scattered around their contracting locations across the country, with different sourcing options for each main type of product at each location. This allows their chefs to create more appealing menus with local food options for their consumers. This also matches the agenda of FHE4's SU with regards to local sourcing.

In terms of incremental change, the use of water fountains around the campus of FHE4 is a typical example. Though water fountains had previously been available around the campus, providing drinking water for students, over time the university had removed them. So the only drinking water available was through the purchase of plastic water bottles. However, the students started to complain, indicating that they preferred water fountains as these reduced the costs of buying plastic bottles of water (financial logic) as well as saving time in going to buy those bottles from the catering outlets between their lectures (time logic). So "once they started to complain and started campaigning, then suddenly the university said wait we may start to do something about this ... the students I think are the most powerful thing that we have, but they have to come together to do that to make it happen" (FHE4-I2). And indeed, the university started to re-operate the old water fountains and build new ones. Here, the financial and time logics of students complemented the 
sustainability logic of the university which facilitated the change in the upstream level of the supply chain. However, this is argued to be incremental change and not radical because it was not further diffused in the upstream supply chain. The university couldn't convince their contractor to completely remove plastic water bottles as they are considered to be one of their most important income generators. So, in this case, the financial logic of the contractor conflicts with the sustainability logic of the university, which makes the sustainability development more incremental in nature.

\section{Discussion}

In comparison to the prior literature, this paper makes three key contributions, as follows:

- In terms of institutional pressures, it: identifies mimetic pressures as being relevant at the focal university tier; and suggests only weak governmental pressures on focal companies and suppliers;

- It suggests a mutual relationship between institutional pressures and logics;

- It provides much needed additional empirical evidence related to institutional complexity by: suggesting a multiplicity of logics across the supply chain rather than a dominant financial logic; suggesting that the relative importance of institutional logics can change over time; and that the level of complexity impacts the extent to which changes in the drive towards SSCM are either radical or incremental.

Each of these contributions is discussed in turn below, in sections 6.1 to 6.3 respectively, leading to the development of three propositions that expand the prior literature on institutional theory. 


\subsection{New findings related to Institutional Pressures}

Firstly, no prior studies have identified mimetic pressures affecting the SSCM practices of universities. In contrast, prior studies focus on strong normative pressures for the focal universities (Clarke and Kouri 2009; Disterheft et al., 2012). For example, the latter found social and environmental awareness/ responsibilities to be the most important driver to implement EMS in European universities. Whilst Table 4 above shows that this study also found strong normative pressures, it adds to the literature by identifying that mimetic pressures also occur due to the influence of the Green League Table and the sharing of best practices within the purchasing consortiums.

Interestingly, in this study the findings suggest very weak governmental pressures on both focal companies and suppliers, despite the existence of governmental regulations and guidelines in this context. This is in contrast to previous studies, where governmental coercive pressures have been shown to play an important role in diffusing SSCM practices (e.g., Zhu and Sarkis, 2007; Wu et al., 2012). As discussed above, this may be due to: governmental standards lagging behind the universities' sustainability policies; the high level of autonomy and independence of university management from governmental interference; and the lack of governmental resources and infrastructure to diffuse and monitor sustainability practices. However, this finding could also indicate the evolution of SSCM to become a more central concern of supply chain actors, thereby making the interaction between them and the societal and market pressures sufficient drivers for sustainable development.

\subsection{A Mutual relationship between Institutional Pressures and Logics}

A second key contribution from this study is that it sheds light on the nature of the relationship between the institutional pressures and institutional logics. The extant literature has studied the shifting of institutional logics, concluding that consistent and continuous institutional pressures contribute in strengthening one institutional logic over another or creating new institutional logics (Thornton and Ocasio 1999; Reay and Hinings, 2005). However the prior literature does not suggest that existing institutional logics influence the manner in which specific institutional pressures are perceived, especially when different institutional pressures are at play. As shown in Table 7, there is some indication that the perception of the pressures may be influenced by the prevailing logics, at least in the short term. It can be argued that a current overriding sustainability logic in the universities, SUs and a few exceptional suppliers makes them perceive normative and mimetic pressures to be 
stronger than coercive pressures, i.e. it can be argued that the sustainability logic makes them much more forward thinking in their practices, thereby going beyond compliance with the minimum requirements as imposed by coercive pressures from external parties. In contrast, in the case of the majority of suppliers where financial logic is overriding, the perception of coercive pressures outweighs the perception of other normative pressures. From these indicators the following proposition can be formed:

Proposition 1: There is a mutual relationship between the institutional pressures and institutional logics. While the institutional pressures can influence changes in the institutional logics in the long run, embedded institutional logics can influence the perception of institutional pressures and their strengths in the short run.

\subsection{Empirical Evidence related to Institutional Complexity}

A third key contribution of this study is the additional empirical evidence related to the theoretical concepts surrounding institutional complexity as developed by Greenwood et al. (2011). In particular, this study suggests a multiplicity of institutional logics across the supply chain. This is in contrast to prior research which has focused on empirical evidence for homogeneity/isomorphism, as demonstrated by Glover et al. (2014) who concluded that financial logic was dominant at every tier. This may be due to the inclusion of public and private sector organisations in this study, whilst Glover et al. (2014) looked at a purely commercial supply chain. Also in terms of consumers, this study has shown how a special type of supply chain consumer (i.e., students) contributes to the multiplicity of institutional logics and how different logics can exist within the consumers' tier as well. Arguably, all this can increase the institutional complexity within the context of SSCM.

In addition, the findings above add to the extant literature which called for further research into the "dynamic patterns of complexity" (Greenwood et al., 2011) by suggesting that the relative importance of competing logics can become more or less prevalent over time. For example, some strategies can increase the cost of implementing sustainability across the supply chain, e.g. local buying may result in higher prices. This in turn can stimulate a greater focus on the financial logic of the university when the costs became unacceptably high. Thus, whilst responses to sustainability challenges can reduce complexity, they can also increase it.

Finally, this study illustrates that the extent to which homogeneity and heterogeneity assumptions are applicable at the supply chain level impacts the potential to achieve radical or incremental change towards SSCM. This can be illustrated given that both homogeneity/ isomorphism (DiMaggio and Powell, 1983) and heterogeneity (Greenwood and Hinings, 
1996; Hoffman, 2001) assumptions are empirically supported at the supply chain level as conceptually illustrated in Figure 3 below.

[Take in Figure 3]

As can be seen on the left hand side of Figure 3, when there is homogeneity in pressures perceived and embedded logic, this can be argued to lead to a more homogenous response in terms of the SSCM practices implemented. When this homogenous response is due to a prevailing sustainability logic across the supply chain, this will lead to a more radical change in SSCM implementation. This is illustrated by the examples of radical change given in section 5.3 above, in which there is evidence of homogeneity across the 'LS5-FHE2-C2Student Consumers' and the 'Con1-FHE4-C4-Student Consumers' supply chains. This has led to sustainable practices across the food supply chain through substantial use of local suppliers; and has also meant that SSCM practices have been extended into other supply chains, such as garment procurement. Therefore it is argued that the data in this study adds to the extant literature by suggesting the following proposition:

Proposition 2: Where sustainability logic prevails at the supply chain level, with supply chain actors most concerned with normative and mimetic pressures, institutional isomorphism/ homogeneity will lead to radical changes in the drive towards SSCM.

In contrast, and as shown in the right-hand side of Figure 3, institutional theory also has the ability to explain heterogeneity (Bunduchi et al., 2008), which is also found in this study. The heterogeneous response appears when the organisations respond to institutional pressures through superficial conformity (Meyer and Rowan, 1977) or through resistance to the institutional demand (Hoffman, 2001). As discussed in the previous literature the embedded institutional logics in the organisations influence their response to different institutional demands, given that this heterogeneity occurs when there is incompatibility between the prevailing logic and specific institutional demand (Greenwood et al., 2010; Greenwood et al., 2011). Also as mentioned in the literature review above there are various impacts of different institutional pressures on the response of the organisations (Clemens and Douglas, 2006; Sarkis et al., 2010; Wu et al., 2012). Therefore, it can be expected that different perceptions of the contending institutional pressures can result in different responses. This study adds to this extant literature by providing empirical evidence that this heterogeneity leads to more incremental changes at the supply chain level, as presented in the right side of Figure 3. As explained in section 5 of the findings above, the data suggests the existence of this heterogeneity between the universities and their suppliers and customers through their deliberate and undeliberate resistance to sustainability practices when they conflict with their 
prevailing logics (financial logic and time logic). However the strategies that the universities implements, as the most salient actor, to tackle the challenges caused by this complexity help to drive SSCM implementation at the supply chain level, albeit in a more incremental manner. This leads to the following proposition:

Proposition 3: Where there is a multiplicity of institutional logics in the supply chain field, with supply chain actors responding in different ways to institutional pressures, institutional heterogeneity will lead to incremental changes in the drive towards SSCM.

\section{Conclusion}

This study contributes to the literature, firstly, by illustrating that the institutional pressures related to SSCM can differ across the different tiers of the supply chain. In particular, it is noted that whilst suppliers experience strong coercive pressures, there is a lack of perceived coercive pressures in the university and consumer tiers of the supply chain. The data suggests that this is due to the organisational attributes of this supply chain - for example the Universities experience more of an ethical obligation and tend to be ahead of government requirements. Secondly, this study suggests that the presence of particular institutional logics lead to differing perceptions of the institutional pressures. This adds understanding to the prior literature, which tends to lack clarity in discussing the relationship between institutional logics and pressures. Thirdly, this paper provides empirical evidence, thereby increasing understanding, of the concept of institutional complexity (Greenwood et al., 2011) in the context of SSCM involving multiple supply chain tiers. This complexity is due in particular to: the multiplicity of logics found across the supply chain; the way that the pressures and logics evolve over time; and the level of saliency associated with position in this interorganisational field. Thus it is concluded that homogeneity and heterogeneity assumptions are both supported within the supply chain, and these phenomena need to be understood before diffusing SSCM practices across the tiers. In this study, the University is the supply chain member that tends to absorb the challenges that arise from the institutional complexity in the context of SSCM and that seeks to find strategies to overcome these challenges.

\subsection{Managerial Implications}

This study can aid procurement practitioners in focal organisations to better understand the reasons for different responses from supply chain actors in different tiers when they try to introduce SSCM initiatives. In particular, the findings illustrate the key role that the 
underpinning institutional logics play in SSCM implementation across the supply chain. Therefore, where there is resistance to new SSCM practices, this is likely to be as a result of conflict in the underlying institutional logics at the supply chain level. Thus, in the short run, the focal organisation is unlikely to be successful in making radical SSCM changes and it may be more realistic to first attempt to influence the institutional logics. This could be achieved, for example, by training programmes run by external bodies such as the purchasing consortiums. In contrast, where there is compatibility of institutional logics across the supply chain, the focal organisation should focus its efforts towards its desired radical changes in SSCM practices. This leads to the conclusion that a better understanding of institutional complexity will lead to better designs for SSCM programs that are not only compatible with the focal organisations' institutional logics, but also with the institutional logics in other tiers, thereby aiming to avoid a heterogeneous response that negatively impacts SSCM implementation.

From a customer's perspective, the findings suggest that the introduction of the Green League Table for Universities (as established by the Student's Union) has become a strong mimetic pressure. Thus, the findings suggest that pressures from customers that encourage competition on a range of sustainability criteria can have a positive impact on SSCM practices. This implies that customer groups in other contexts may also be able to exert a similar level of influence through the creation of similar league tables.

The managerial implications for the suppliers depend on the institutional logics of those suppliers - i.e. on the contextual factors related to the institutional environment. For those with a dominant sustainability logic, such as LS5, the research suggests that they will need to identify customers who already share the same logic or whom they can influence in order to readily diffuse SSCM practices across the supply chain. For those that are resistant to new SSCM practices and have a dominant financial logic, it will be important for them to seek win-win solutions that allow them to go some way towards implementing the changes their customers require, but without compromising their financial sustainability.

\subsection{Limitations and Future Research}

A limitation of this study is its focus on food supply chains. Other product supply chains may provide further insight into institutional complexity within SSCM. For example, it could be expected that suppliers of other products that have a more direct and significant impact on the environment (e.g. chemical products suppliers) have more compatible institutional logics with focal organisation's institutional logics, which in turn reduces institutional complexity. 
In addition, the research is limited in the extent to which it captures the student consumer viewpoint, given that this viewpoint is currently based on the opinions of student union representatives. It will be particularly important for future research to investigate whether the student union representatives have been able to adequately represent the views of student consumers. For example, direct interviews with a wide variety of student consumers may be needed and/or a survey of a large number of students. Also this study is limited to the inclusion of three tiers of the supply chain. To address this limitation, future research could include more tiers, ideally from the upmost upstream end to the furthest downstream tier thereby including end consumers, to provide a more comprehensive description of institutional complexity at the supply chain level within the context of SSCM. Lastly, future research could further investigate the three propositions that have been developed in the discussion section above.

\section{Appendix}

Table A1 below lists the interview questions used for the focal Universities, and illustrates how these questions were used to investigate the three main constructs of Institutional Pressures, Institutional Logics and Institutional Complexity. Similar questions were used for the supplier and customer tiers of the supply chain, though modified slightly as appropriate to the tier.

[Take in Table A1] 


\section{References}

Alford, R. R. \& Friedland, R. 1985. Powers of Theory: Capitalism, the State, and Democracy. Cambridge: Cambridge University Press.

Besharov, M. L. \& Smith, W. K. 2014. Multiple institutional logics in organizations: Explaining their varied nature and implications. Academy of Management Review, 39, 364-381.

Bhakoo, V. \& Choi, T. 2013. The iron cage exposed: Institutional pressures and heterogeneity across the healthcare supply chain. Journal of Operations Management, 31, 432-449.

Bunduchi, R., Graham, I., Smart, A. \& Williams, R. 2008. Homogeneity and heterogeneity in information technology private standard settings - the institutional account. Technology Analysis \& Strategic Management, 20, 389-407.

Carter, C.R. \& Rogers, D.S. 2008. A framework of sustainable supply chain management: moving toward new theory. International Journal of Physical Distribution \& Logistics Management, 38, 360-387.

Clarke, A. \& Kouri, R. 2009. Choosing an appropriate university or college environmental management system. Journal of Cleaner Production, 17, 971-984.

Clemens, B. \& Douglas, T. J. 2006. Does coercion drive firms to adopt 'voluntary' green initiatives? Relationships among coercion, superior firm resources, and voluntary green initiatives. Journal of Business Research, 59, 483-491.

Czinkota, M., Kaufmann, H. R. \& Basile, G. 2014. The relationship between legitimacy, reputation, sustainability and branding for companies and their supply chains. Industrial Marketing Management, 43, 91-101.

DiMaggio, P. J. \& Powell, W. W. 1983. The Iron Cage Revisited: Institutional Isomorphism and Collective Rationality in Organizational Fields. American Sociological Review, 48, 147-160.

Disterheft, A., Ferreira Da Silva Caeiro, S. S., Ramos, M. R. \& De Miranda Azeiteiro, U. M. 2012. Environmental Management Systems (EMS) implementation processes and practices in European higher education institutions - Top-down versus participatory approaches. Journal of Cleaner Production, 31, 80-90.

Eisenhardt, K. M. 1989. Building Theories from Case Study Research. The Academy of Management Review, 14, 532-550.

Eisenhardt, K.M. \& Graebner, M.E. 2007. Theory building from cases: opportunities and challenges Academy of Management Journal, 50, 25-32.

Gawer, A. \& Phillips, N. 2013. Institutional Work as Logics Shift: The Case of Intel's Transformation to Platform Leader. Organization Studies, 34, 1035-1071.

Glover, J. L., Champion, D., Daniels, K. J. \& Dainty, A. J. D. 2014. An Institutional Theory perspective on sustainable practices across the dairy supply chain. International Journal of Production Economics, 152, 102-111.

Greenwood, R. \& Hinings, C. R. 1996. Understanding Radical Organizational Change: Bringing together the Old and the New Institutionalism. The Academy of Management Review, 21, 1022-1054.

Greenwood, R., Díaz, A. M., Li, S. X. \& Lorente, J. C. 2010. The Multiplicity of Institutional Logics and the Heterogeneity of Organizational Responses. Organization Science, 21, 521-539.

Greenwood, R., Raynard, M., Kodeih, F., Micelotta, E. R. \& Lounsbury, M. 2011. Institutional Complexity and Organizational Responses. The Academy of Management Annals, 5, 317-371. 
Grosvold, J., Hoejmose, S. U. \& Roehrich, J. K. 2014. Squaring the circle: Management, measurement and performance of sustainability in supply chains. Supply Chain Management: An International Journal, 19, 292-305.

Heiskanen, E. 2002. The institutional logic of life cycle thinking. Journal of Cleaner Production, 10, 427-437.

Hoffman, A. J. 2001. Linking Organizational and Field-Level Analyses: The Diffusion of Corporate Environmental Practice. Organization \& Environment, 14, 133-156.

Ketokivi, M. \& Choi, T. 2014. Renaissance of case research as a scientific method. Journal of Operations Management, 32, 232-240.

March, J. \& Olsen, J. 1984. The New Institutionalism: Organisational Factors in Political Life. American Political Science Review, 78: 738 -49.

Meyer, J. W. \& Rowan, B. 1977. Institutionalized Organizations: Formal Structure as Myth and Ceremony. American Journal of Sociology, 83, 340-363.

Miemczyk, J., Johnsen, T. E. \& Macquet, M. 2012. Sustainable purchasing and supply management: a structured literature review of definitions and measures at the dyad, chain and network levels. Supply Chain Management: An International Journal, 17, 478-496.

Moxham, C. \& Kauppi, K. 2014. Using organisational theories to further our understanding of socially sustainable supply chains: The case of fair trade. Supply Chain Management: An International Journal, 19, 413-420.

Miles, M.B., Huberman, A.M. \& SaldañA, J. 2014. Qualitative data analysis: a methods sourcebook, Los Angeles, Calif., SAGE Publications Inc.

Oglethorpe, D. \& Heron, G. 2013. Testing the theory of constraints in UK local food supply chains. International Journal of Operations \& Production Management, 33, 1346-1367.

Reay, T. \& Hinings, C. R. 2005. The Recomposition of an Organizational Field: Health Care in Alberta. Organization Studies, 26, 351-384.

Sarkis, J., Gonzalez-Torre, P. \& Adenso-Diaz, B. 2010. Stakeholder pressure and the adoption of environmental practices: The mediating effect of training. Journal of Operations Management, 28, 163-176.

Sarkis, J., Zhu, Q. \& Lai, K.-H. 2011. An organizational theoretic review of green supply chain management literature. International Journal of Production Economics, 130, 1-15.

Saunders, M., Lewis, P. \& Thornhill, A. 2016. Research methods for business students, Harlow, Pearson Education.

Svensson, G. 2007. Aspects of sustainable supply chain management (SSCM): conceptual framework and empirical example. Supply Chain Management: An International Journal, 12, 262-266.

Tate, W.L., Dooley, K.J. \& Ellram, L.M. 2011. Transaction Cost and Institutional Drivers of Supplier Adoption of Environmental Practices. Journal of Business Logistics, 32, 6-16.

Thornton, P.H., \& Ocasio, W. 1999. Institutional logics and the historical contingency of power in organizations: Executive succession in the higher education publishing industry, 1958-1990. American Journal of Sociology, 105, 801-843.

Thornton, P.H. 2004. Markets from culture: Institutional logics and organizational decisions in higher education publishing. Stanford, CA: Stanford University Press.

Thornton, P.H., \& Ocasio, W. 2008. Institutional logics. In R. Greenwood, C. Oliver, K. Sahlin, \& R. Suddaby (Eds.), The SAGE handbook of organizational institutionalism (pp. 99-129). London: Sage.

Varsei, M., Soosay, C., Fahimnia, B. \& Sarkis, J. 2014. Framing sustainability performance of supply chains with multidimensional indicators. Supply Chain Management: An International Journal, 19, 242-257.

Voss, C. 2009. Case Research in Operations Management. In: Karlsson, C. (ed.) Researching Operations Management. 1st ed ed. New York: Routledge. 
Wooten, M. \& Hoffman, A. 2008. Organizational fields: Past, present and future. In R. Greenwood, C. Oliver, K. Sahlin, \& R. Suddaby (Eds.), The SAGE handbook of organizational institutionalism (pp. 1-46). London: Sage.

Wu, G.-C., Ding, J.-H. \& Chen, P.-S. 2012. The effects of GSCM drivers and institutional pressures on GSCM practices in Taiwan's textile and apparel industry. International Journal of Production Economics, 135, 618-636.

Wu, T., Daniel, E. M., Hinton, M. \& Quintas, P. 2013. Isomorphic mechanisms in manufacturing supply chains: a comparison of indigenous Chinese firms and foreignowned MNCs. Supply Chain Management: An International Journal, 18, 161-177.

Yin, R.K. 2009. Case study research: design and methods, Los Angeles, Calif., Sage Publications.

Zhu, Q. \& Sarkis, J. 2007. The moderating effects of institutional pressures on emergent green supply chain practices and performance. International Journal of Production Research, 45, 4333-4355.

Zorzini, M., Hendry, L. C., Huq, F. A. \& Stevenson, M. 2015. Socially responsible sourcing: reviewing the literature and its use of theory. International Journal of Operations \& Production Management, 35, 60-109. 
Tables and Figures

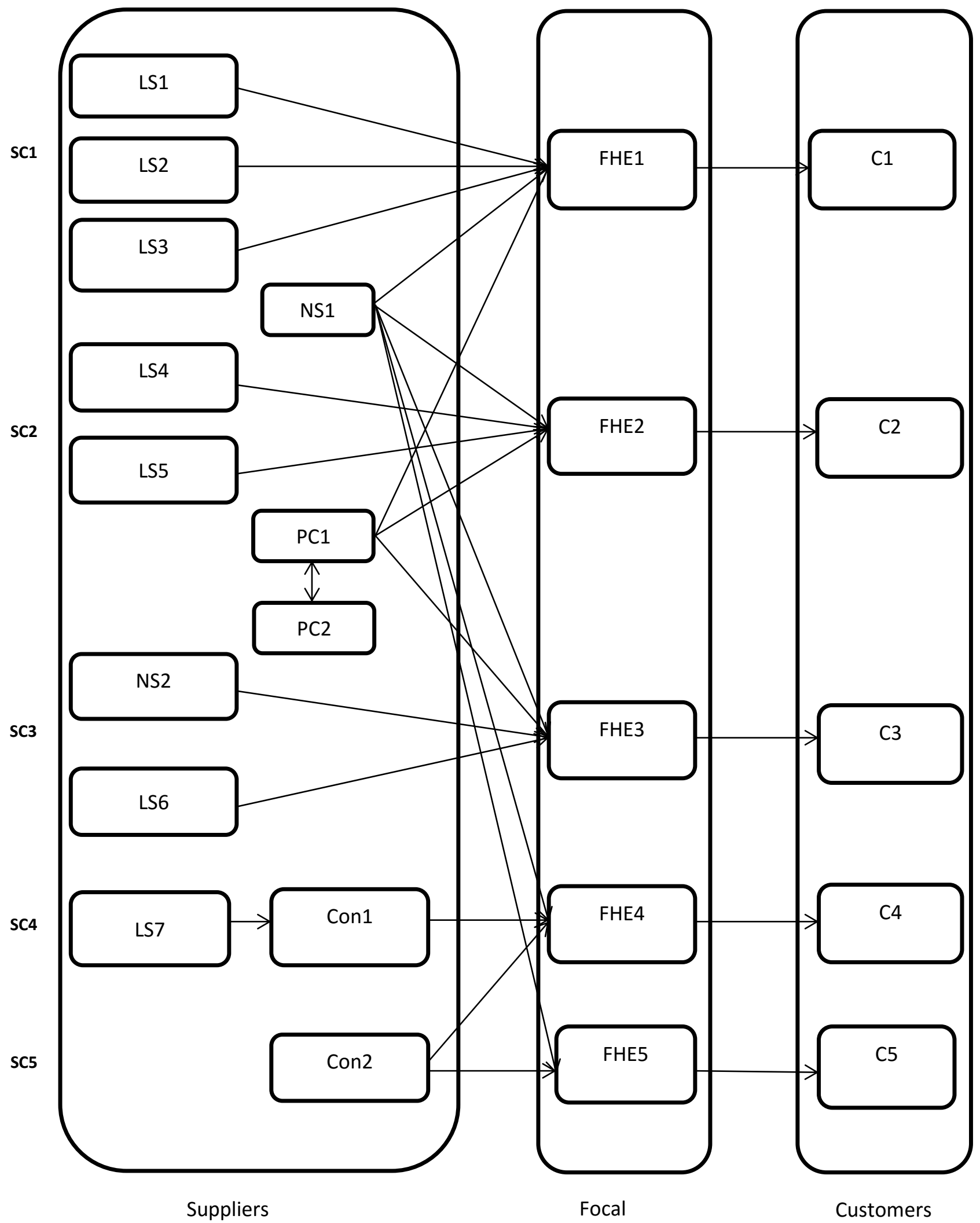

Figure 1: Food and Catering Supply Chains of the five HE Institutions under study 


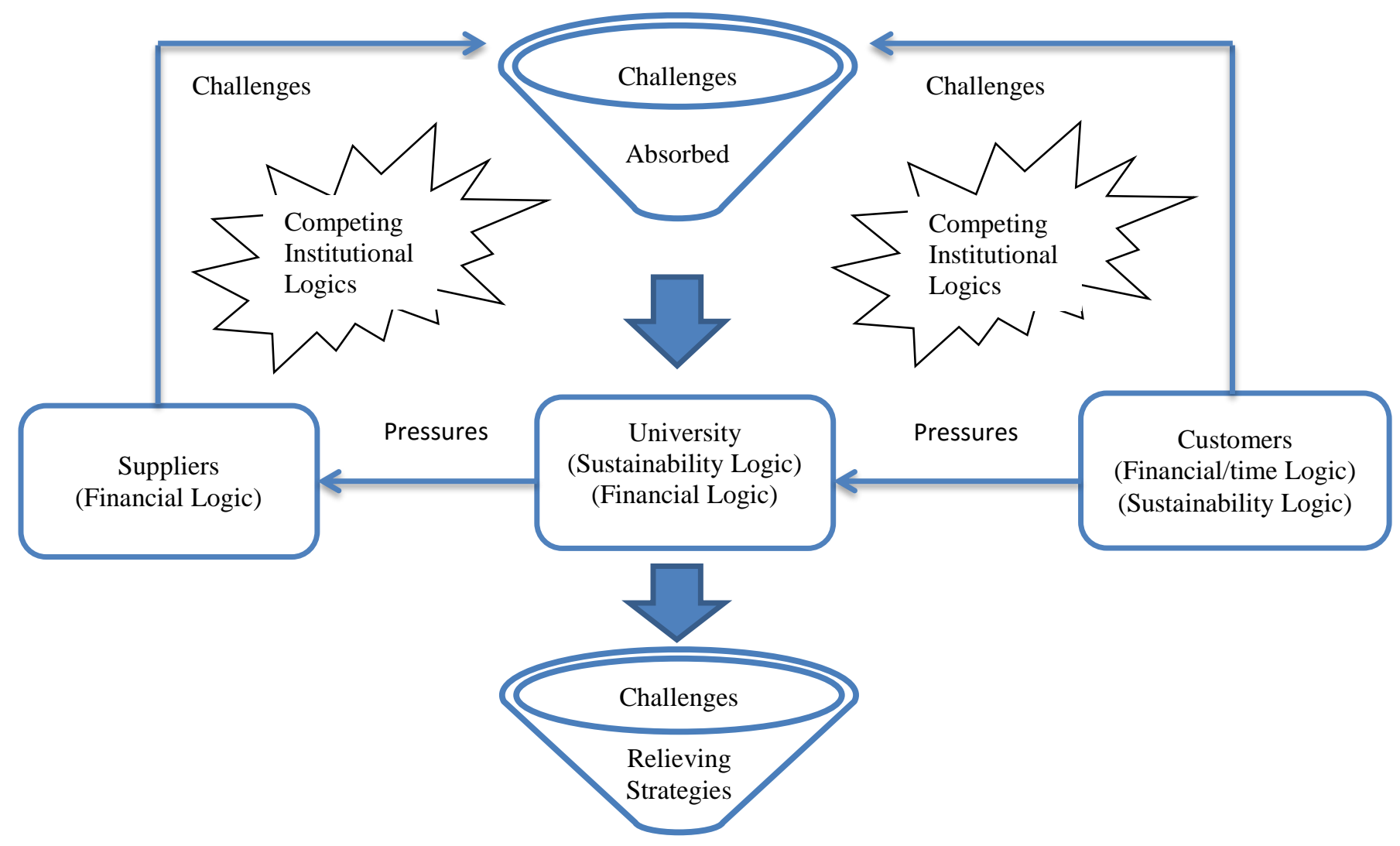

Figure 2- Institutional Complexity in the UK HE Food and Catering Supply Chain 


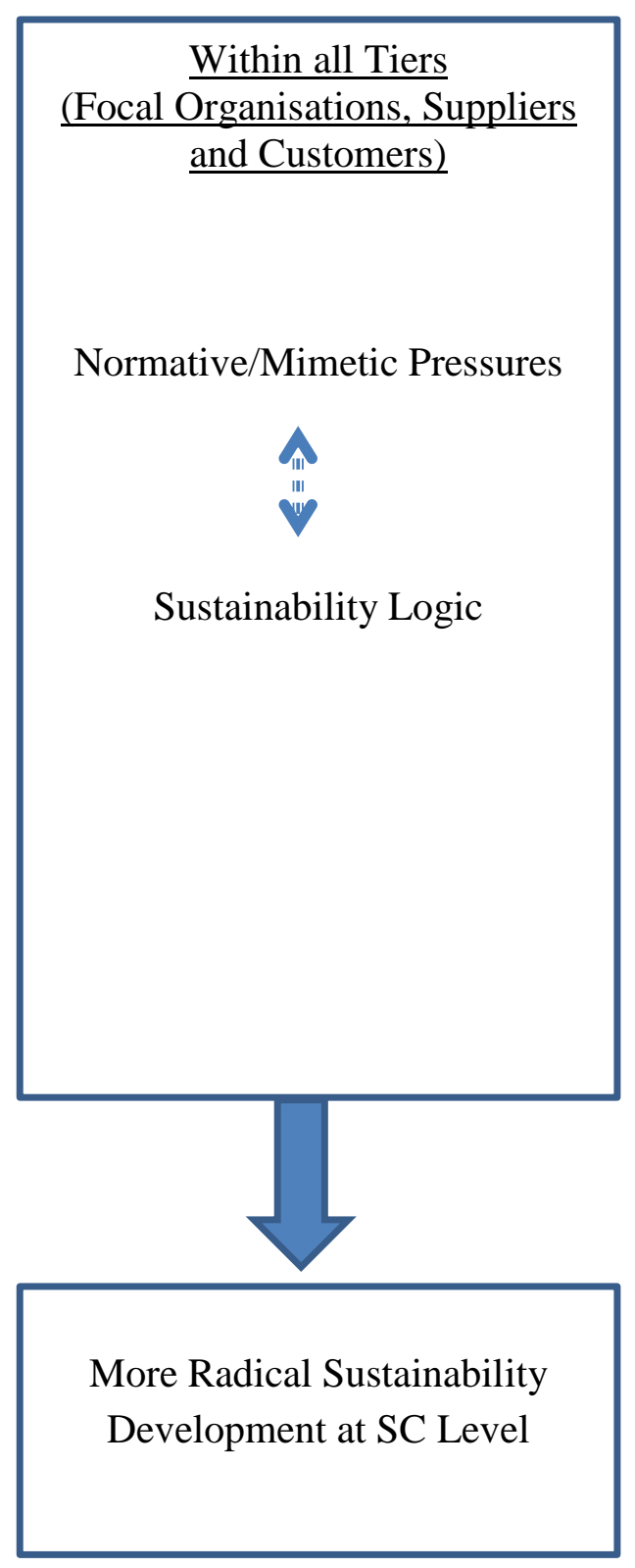

$\underline{\text { Within Focal Organisation Tier }}$

Normative/Mimetic Pressures

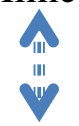

Sustainability Logic

$\underline{\text { Within Suppliers' Tier }}$

Coercive Pressures

Financial Logic

$\underline{\text { Within Customers' Tier }}$

Sustainability/Financial/Time Logic

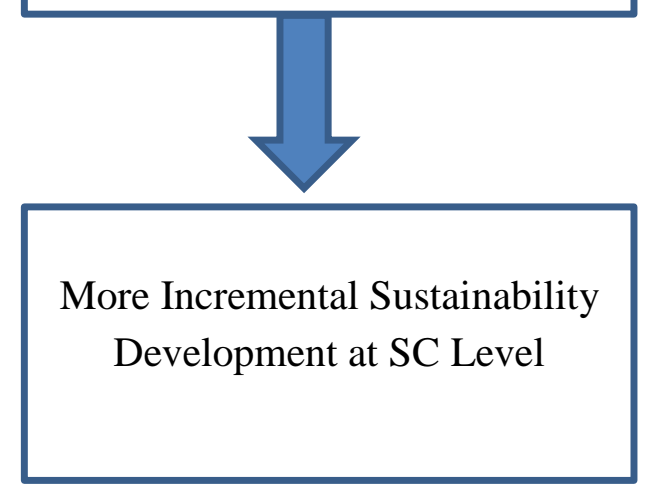

Figure 3: The impact of Homogeneity/ Heterogeneity on SSCM 
Table 1: Organisation and Interviewee Details

\begin{tabular}{|c|c|c|c|c|c|c|}
\hline $\begin{array}{l}\text { Nature of the } \\
\text { Business }\end{array}$ & $\begin{array}{l}\text { Product and } \\
\text { Services }\end{array}$ & $\begin{array}{l}\text { Position in } \\
\text { the Supply } \\
\text { Chain } \\
\end{array}$ & $\begin{array}{l}\text { Position of } \\
\text { Interviewee }\end{array}$ & $\begin{array}{l}\text { Number of } \\
\text { Interviews }\end{array}$ & $\begin{array}{l}\text { Length of } \\
\text { Interviews }\end{array}$ & $\begin{array}{l}\text { Reference } \\
\text { Mnemonic } \\
\end{array}$ \\
\hline \multirow{4}{*}{ University } & \multirow{4}{*}{$\begin{array}{l}\text { Higher } \\
\text { Education } \\
\text { Services } \\
\text { (In-House } \\
\text { Catering) }\end{array}$} & \multirow{4}{*}{$\begin{array}{c}\text { Focal } \\
\text { Organisation }\end{array}$} & $\begin{array}{l}\text { Procurement } \\
\text { Manager }\end{array}$ & 1 & $1 \mathrm{hr}$ & FHE1-I1 \\
\hline & & & $\begin{array}{l}\text { Food Operations } \\
\text { Manager }\end{array}$ & 1 & $1.5 \mathrm{hr}$ & FHE1-I2 \\
\hline & & & $\begin{array}{c}\text { Executive Head } \\
\text { Chef }\end{array}$ & 1 & $1.75 \mathrm{hr}$ & FHE1-I3 \\
\hline & & & $\begin{array}{l}\text { Project Team } \\
\text { Leader } \\
\end{array}$ & 2 & $2 \mathrm{hr}$ & FHE1-I4 \\
\hline \multirow{2}{*}{ University } & \multirow{2}{*}{$\begin{array}{l}\text { Higher } \\
\text { Education } \\
\text { Services } \\
\text { (In-House } \\
\text { Catering) }\end{array}$} & \multirow{2}{*}{$\begin{array}{c}\text { Focal } \\
\text { Organisation }\end{array}$} & $\begin{array}{c}\text { Head of } \\
\text { Hospitality \& } \\
\text { Events }\end{array}$ & 1 & $1 \mathrm{hr}$ & FHE2-I1 \\
\hline & & & $\begin{array}{c}\text { Executive Head } \\
\text { Chef }\end{array}$ & 1 & $1 \mathrm{hr}$ & FHE2-I2 \\
\hline \multirow[b]{2}{*}{ University } & \multirow{2}{*}{$\begin{array}{c}\text { Higher } \\
\text { Education } \\
\text { Services } \\
\text { (In-House } \\
\text { Catering) }\end{array}$} & \multirow{2}{*}{$\begin{array}{c}\text { Focal } \\
\text { Organisation }\end{array}$} & $\begin{array}{c}\text { Catering Services } \\
\text { Manager }\end{array}$ & 1 & $1 \mathrm{hr}$ & FHE3-I1 \\
\hline & & & Conference Officer & 1 & $0.5 \mathrm{hr}$ & FHE3-I2 \\
\hline \multirow[b]{2}{*}{ University } & \multirow{2}{*}{$\begin{array}{c}\text { Higher } \\
\text { Education } \\
\text { Services } \\
\text { (Outsourced } \\
\text { Catering) }\end{array}$} & \multirow[b]{2}{*}{$\begin{array}{c}\text { Focal } \\
\text { Organisation }\end{array}$} & $\begin{array}{l}\text { Procurement } \\
\text { Officer }\end{array}$ & 1 & $1.25 \mathrm{hr}$ & FHE4-I1 \\
\hline & & & $\begin{array}{c}\text { Head of Catering } \\
\text { and Conferences } \\
\text { Services }\end{array}$ & 1 & $1 \mathrm{hr}$ & FHE4-I2 \\
\hline \multirow[b]{2}{*}{ University } & \multirow{2}{*}{$\begin{array}{c}\text { Higher } \\
\text { Education } \\
\text { Services } \\
\text { (Outsourced } \\
\text { Catering) } \\
\end{array}$} & \multirow{2}{*}{$\begin{array}{c}\text { Focal } \\
\text { Organisation }\end{array}$} & $\begin{array}{c}\text { Procurement } \\
\text { Category Manager }\end{array}$ & 1 & $1.75 \mathrm{hr}$ & FHE5-I1 \\
\hline & & & $\begin{array}{l}\text { Environmental } \\
\text { Officer }\end{array}$ & 1 & $1 \mathrm{hr}$ & FHE5-I2 \\
\hline $\begin{array}{c}\text { Food and } \\
\text { Catering } \\
\text { Consortium }\end{array}$ & $\begin{array}{l}\text { Procurement } \\
\text { Professional } \\
\text { Services, } \\
\text { Suppliers } \\
\text { Frameworks } \\
\end{array}$ & $\begin{array}{c}\text { Liaison } \\
\text { between } \\
\text { universities } \\
\text { and suppliers }\end{array}$ & $\begin{array}{c}\text { Chief Operating } \\
\text { Officer }\end{array}$ & 1 & $1.5 \mathrm{hr}$ & $\mathrm{PC} 1$ \\
\hline $\begin{array}{l}\text { Food and } \\
\text { Catering } \\
\text { Consortium }\end{array}$ & $\begin{array}{l}\text { Procurement } \\
\text { Professional } \\
\text { Services, } \\
\text { Suppliers } \\
\text { Frameworks }\end{array}$ & $\begin{array}{c}\text { Liaison } \\
\text { between } \\
\text { universities } \\
\text { and suppliers }\end{array}$ & Specialist Adviser & 1 & $1.5 \mathrm{hr}$ & $\mathrm{PC} 2$ \\
\hline $\begin{array}{l}\text { Food and } \\
\text { Catering } \\
\text { Contractor } \\
\end{array}$ & $\begin{array}{l}\text { Food and } \\
\text { Catering } \\
\text { Services } \\
\end{array}$ & $\begin{array}{l}\text { Contractor/ } \\
\text { Supplier }\end{array}$ & $\begin{array}{c}\text { Head of } \\
\text { Sustainability } \\
\text { Business } \\
\end{array}$ & 1 & $1 \mathrm{hr}$ & Con1 \\
\hline $\begin{array}{l}\text { Catering and } \\
\text { Facilities } \\
\text { Management } \\
\text { Contractor }\end{array}$ & $\begin{array}{l}\text { Catering and } \\
\text { Facilities } \\
\text { Management } \\
\text { Services }\end{array}$ & $\begin{array}{l}\text { Contractor/ } \\
\text { Supplier }\end{array}$ & Contract Director & 1 & $1 \mathrm{hr}$ & Con2 \\
\hline $\begin{array}{l}\text { Fruit and Veg } \\
\text { Wholesaler }\end{array}$ & $\begin{array}{c}\text { Fruit, } \\
\text { Vegetables, } \\
\text { Prepared } \\
\text { Vegetables, } \\
\text { Milk }\end{array}$ & $\begin{array}{l}\text { Tier } 1 \text { Local } \\
\text { Supplier }\end{array}$ & Managing Director & 1 & $1 \mathrm{hr}$ & LS1 \\
\hline $\begin{array}{l}\text { Cheese and } \\
\text { butters } \\
\text { Manufacturer }\end{array}$ & $\begin{array}{l}\text { Cheese, } \\
\text { Butter, } \\
\text { Contract } \\
\text { Packing }\end{array}$ & $\begin{array}{l}\text { Tier } 1 \text { Local } \\
\text { Supplier }\end{array}$ & Managing Director & 1 & $0.75 \mathrm{hr}$ & LS2 \\
\hline $\begin{array}{c}\text { Meat and } \\
\text { Poultry } \\
\text { Wholesaler } \\
\end{array}$ & $\begin{array}{l}\text { Fresh Meat, } \\
\text { Poultry, } \\
\text { Game } \\
\end{array}$ & $\begin{array}{l}\text { Tier } 1 \text { Local } \\
\text { Supplier }\end{array}$ & Managing Director & 1 & $1.5 \mathrm{hr}$ & LS3 \\
\hline $\begin{array}{c}\text { Food Grocery } \\
\text { Wholesaler }\end{array}$ & $\begin{array}{c}\text { Fruits, } \\
\text { Vegetables, } \\
\text { Bakery, Other }\end{array}$ & $\begin{array}{l}\text { Tier } 1 \text { Local } \\
\text { Supplier }\end{array}$ & $\begin{array}{l}\text { Sales Office } \\
\text { Supervisor }\end{array}$ & 1 & $1 \mathrm{hr}$ & LS4 \\
\hline
\end{tabular}




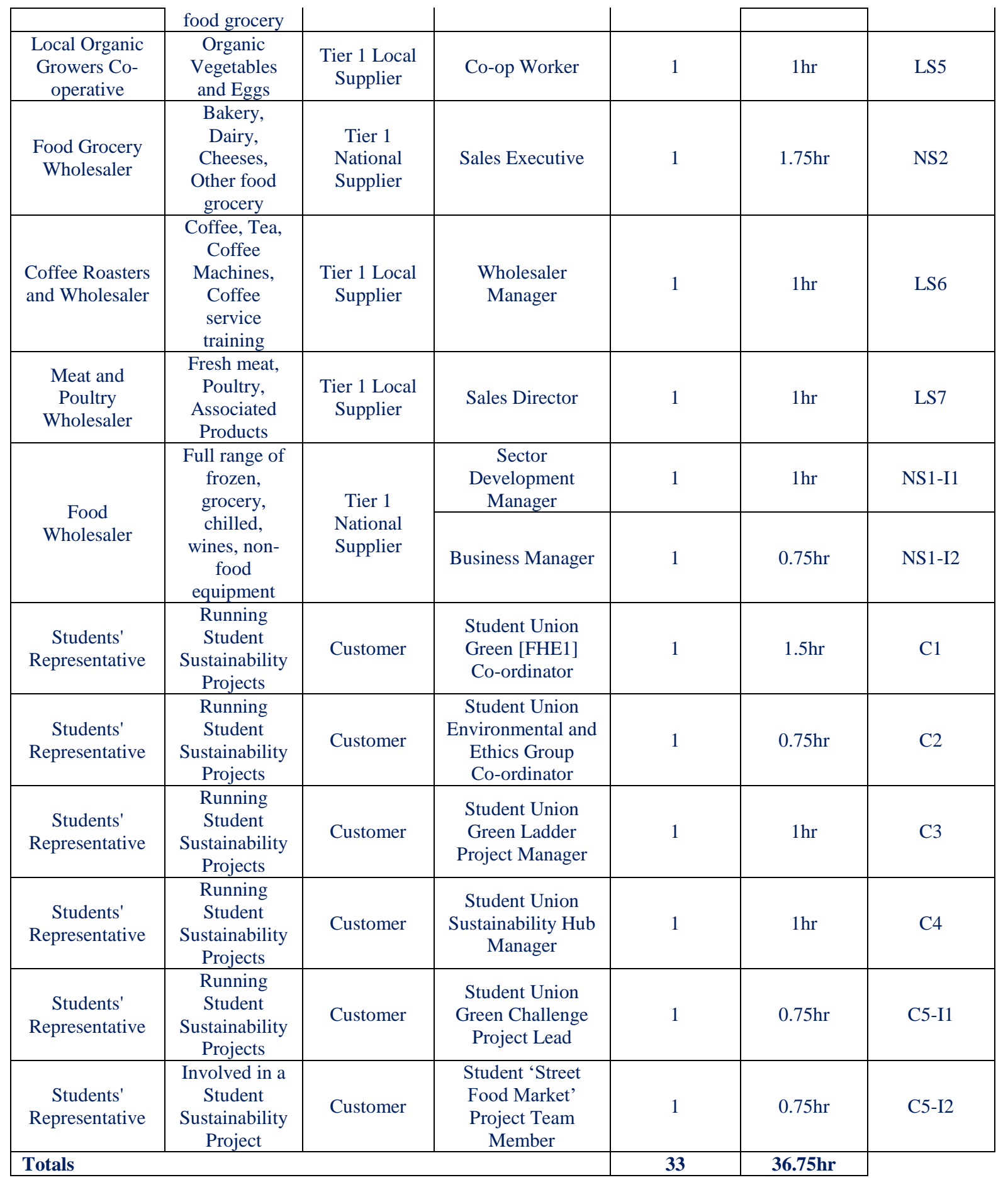


Table 2: Definitions of Key Institutional Theory Constructs

\begin{tabular}{|c|l|c|}
\hline Constructs & \multicolumn{1}{|c|}{ Definition } & Source \\
\hline $\begin{array}{c}\text { Institutional } \\
\text { Pressures }\end{array}$ & $\begin{array}{l}\text { "Mechanisms through which institutional } \\
\text { isomorphic change occurs, each with its own } \\
\text { antecedents". }\end{array}$ & $\begin{array}{c}\text { DiMaggio and } \\
\text { Powell (1983, } \\
\text { p:150) }\end{array}$ \\
\hline Institutional Logic & $\begin{array}{l}\text { "Assumptions and values, usually implicit, } \\
\text { about how to interpret organizational reality, } \\
\text { what constitutes appropriate behaviour, and } \\
\text { how to succeed". }\end{array}$ & $\begin{array}{c}\text { Thornton (2004, } \\
\text { p: } 70)\end{array}$ \\
\hline $\begin{array}{c}\text { Institutional } \\
\text { Complexity }\end{array}$ & $\begin{array}{l}\text { The metaphorical position the organisations find } \\
\text { themselves in "whenever they confront } \\
\text { incompatible prescriptions from multiple } \\
\text { institutional logics". }\end{array}$ & $\begin{array}{c}\text { Greenwood } \text { et al. } \\
\text { (2011, p:317) }\end{array}$ \\
\hline
\end{tabular}

Table 3: Codes used for Data Analysis in NVIVO

\begin{tabular}{|c|c|c|}
\hline First-Level Codes & Second-Level Codes & Third-Level Codes \\
\hline \multirow[t]{10}{*}{ Institutional Pressures } & \multirow[t]{2}{*}{ Coercive Pressures } & Legal Obligation \\
\hline & & Customers' Requirements \\
\hline & \multirow[t]{4}{*}{ Normative Pressures } & Ethical Obligation \\
\hline & & Internal Corporate Social Responsibility \\
\hline & & Professionalism Identity \\
\hline & & Industry Norms \\
\hline & \multirow[t]{4}{*}{ Mimetic Pressures } & Green League Table \\
\hline & & Consortium Platform \\
\hline & & Best Practices \\
\hline & & Competition \\
\hline \multirow[t]{3}{*}{ Institutional Logics } & Sustainability-Logic & $\mathrm{n} / \mathrm{a}$ \\
\hline & Financial-Logic & $\mathrm{n} / \mathrm{a}$ \\
\hline & Time-Logic & $\mathrm{n} / \mathrm{a}$ \\
\hline \multirow{17}{*}{ Institutional Complexity } & \multirow{2}{*}{$\begin{array}{l}\text { Institutional Logic } \\
\text { Conflicts (Causes) }\end{array}$} & Sustainability Logic versus Financial Logic \\
\hline & & Sustainability Logic versus Time Logic \\
\hline & \multirow[t]{11}{*}{ Challenges (Symptoms) } & Buyer Resistance \\
\hline & & Contractor Resistance \\
\hline & & Availability \\
\hline & & Clients Resistance \\
\hline & & Contradictory Needs \\
\hline & & Cost and Affordability \\
\hline & & Customer Sluggishness \\
\hline & & Marketing \& Communications \\
\hline & & Local Buying \& Consortium \\
\hline & & Local Suppliers Capabilities \\
\hline & & Logistics Capabilities \\
\hline & \multirow[t]{2}{*}{ Managing Complexity } & Reactive Strategies \\
\hline & & Proactive Strategies \\
\hline & \multirow[t]{2}{*}{ Outcomes } & Radical Sustainability Development \\
\hline & & Incremental Sustainability Development \\
\hline
\end{tabular}


Table 4: Key Institutional Pressures across the Supply Chain

\begin{tabular}{|c|c|c|c|c|}
\hline $\begin{array}{c}\text { Supply Chain } \\
\text { Tier }\end{array}$ & $\begin{array}{c}\text { Institutional } \\
\text { Pressures }\end{array}$ & Sources of Pressures & Sample Quotes & $\begin{array}{l}\text { Cases } \\
\text { perceiving } \\
\text { this } \\
\text { pressure }\end{array}$ \\
\hline $\begin{array}{l}\text { Focal Companies } \\
\text { (Universities) }\end{array}$ & $\begin{array}{l}\text { Normative } \\
\text { Mimetic }\end{array}$ & $\begin{array}{l}\text { Stem from ethical } \\
\text { obligations, internal } \\
\text { sustainability policies, } \\
\text { and professionalism } \\
\text { identity and industry } \\
\text { norms } \\
\text { Stem from Green } \\
\text { League Table } \\
\text { competition and } \\
\text { sharing the best } \\
\text { practices within the } \\
\text { purchasing } \\
\text { consortiums }\end{array}$ & $\begin{array}{l}\text { "The university as an organisation has to be seen to be practicing what it } \\
\text { preaches and people expect a lot from the university in terms of leading the way } \\
\text { on green initiatives and moving towards sustainability." (FHE1-I4) } \\
\text { "It is strong pressure to pursue the professionalism trends." (FHE4-I2) } \\
\text { "The one thing that we view helps drive stuff here at the university, and this has } \\
\text { been a very fortunate thing for us, is that one of the university's four strategic } \\
\text { KPIs happens to be our performance on the people and planet or in other words } \\
\text { the universities league." (FHE5-I2) }\end{array}$ & $\begin{array}{l}\text { FHE1, FHE2, } \\
\text { FHE3, FHE4, } \\
\text { FHE5 } \\
\text { FHE1, FHE2, } \\
\text { FHE3, FHE4, } \\
\text { FHE5 }\end{array}$ \\
\hline Suppliers & Coercive & $\begin{array}{l}\text { Stem from customers' } \\
\text { requirements }\end{array}$ & $\begin{array}{l}\text { "Our most recent initiative that really we joined up, and it's really a process of } \\
\text { jumping through the hoops, would be the Red Tractor initiative, so we've signed } \\
\text { up for that and I would say that was largely driven by the requirements of the } \\
\text { University, the University is only the person that we deal with that has that } \\
\text { requirement." (LS3-FHE1) } \\
\text { "It's driven by customers, it's what they want, it's about ticking that box for the } \\
\text { university as well, because they [the university] are driven by these } \\
\text { environmental things - what they do towards saving carbon footprint, where } \\
\text { they get their products from, what company they are using, to tick that box" }\end{array}$ & $\begin{array}{l}\text { LS1, LS2, } \\
\text { LS3, LS4, } \\
\text { LS6, LS7, } \\
\text { NS1, NS2, } \\
\text { Con1, Con } 2\end{array}$ \\
\hline
\end{tabular}




\begin{tabular}{|c|c|c|c|c|}
\hline & & & $\begin{array}{l}\text { (NS1-I1) } \\
\text { "Yes definitely it [sustainability] is growing in importance. I think the reason for } \\
\text { that is that some clients in universities, schools and colleges won't even think to } \\
\text { do any business with anybody unless they have the accreditations and they have } \\
\text { the potential to do things correctly... It is driven by our clients" (Con2) }\end{array}$ & \\
\hline $\begin{array}{l}\text { Customers } \\
\text { (Students' } \\
\text { Union) }\end{array}$ & Normative & $\begin{array}{l}\text { Stem from ethical } \\
\text { obligation and } \\
\text { behaviours and norms } \\
\text { changes }\end{array}$ & $\begin{array}{l}\text { "... there is a social norm for it. For example if something is perceived as the } \\
\text { standard and if the conscience is raised about these issues, people start shifting } \\
\text { their behaviours." (C1) }\end{array}$ & $\begin{array}{l}\text { C1, C3, C4, } \\
\text { C5 }\end{array}$ \\
\hline
\end{tabular}


Table 5: Key Institutional Logics across the Supply Chain

\begin{tabular}{|c|c|c|c|}
\hline $\begin{array}{c}\text { Supply Chain } \\
\text { Tier }\end{array}$ & $\begin{array}{l}\text { Institutional } \\
\text { Logics }\end{array}$ & Sample Quotes & $\begin{array}{l}\text { Cases with } \\
\text { this } \\
\text { prevailing } \\
\text { logic }\end{array}$ \\
\hline $\begin{array}{l}\text { Focal } \\
\text { Companies } \\
\text { (Universities) }\end{array}$ & $\begin{array}{l}\text { Sustainability } \\
\text { Logic } \\
\text { Financial Logic }\end{array}$ & $\begin{array}{l}\text { "Before, our emphasis was more about the cost than concern about where they get their food from, but in the last } \\
\text { five or six years the emphasis has been changed and sustainability is much stronger." (FHE4-I1) } \\
\text { "We use the policy [attached] as a guide line, but also it has got to be commercially viable, we don't do it at any cost } \\
\text { because we can't because we would be questioned on that, because whilst catering is subsidised to a certain degree, } \\
\text { it would be wrong if everything was organic at the expense of us having to charge students a lot of money for } \\
\text { whatever they are buying, so yes it should be a balance really". (FHE2-I1) }\end{array}$ & $\begin{array}{l}\text { FHE1, FHE2, } \\
\text { FHE3, FHE4, } \\
\text { FHE5 } \\
\text { FHE1, FHE2, } \\
\text { FHE3, FHE4, } \\
\text { FHE5 }\end{array}$ \\
\hline Suppliers & Financial Logic & $\begin{array}{l}\text { "Well, it's [sustainability] always there, it's always relevant, but ultimately it has to make business sense for what we } \\
\text { are doing. If it is making business sense then we will pursue it, if it costs money to do it or there is no return on our } \\
\text { investment, there's no sense in looking at it." (LS2) }\end{array}$ & $\begin{array}{l}\text { LS1, LS2, LS3, } \\
\text { LS4, LS6, LS7, } \\
\text { N1, N2, } \\
\text { Con1, Con2 }\end{array}$ \\
\hline $\begin{array}{l}\text { Customers } \\
\text { (Students' } \\
\text { Union) }\end{array}$ & $\begin{array}{l}\text { Sustainability } \\
\text { Logic }\end{array}$ & $\begin{array}{l}\text { "Our main idea is to engage [FHE5's] students with sustainability - environmental, social and economic initiatives. } \\
\text { We help students to start their own sustainability projects and we opened that up for staff and academics as well in } \\
\text { the second year of the project". (C5) }\end{array}$ & $\begin{array}{l}\mathrm{C} 1, \mathrm{C} 2, \mathrm{C} 3 \\
\mathrm{C} 4, \mathrm{C} 5\end{array}$ \\
\hline $\begin{array}{l}\text { Student } \\
\text { Consumers }\end{array}$ & $\begin{array}{l}\text { Financial Logic } \\
\text { Time Logic }\end{array}$ & $\begin{array}{l}\text { "We have a convenience store and whenever we try to put for example organic eggs or free range students complain } \\
\text { because they want the choice to have a lower price. So the price is really what matter to students." (C4) } \\
\text { "I think the key problem we have is that there are a lot of competing demands on the time of students. There are a } \\
\text { lot of things they need to do, course works, assignments, dissertations, going out socialising, etc. etc., clubs and } \\
\text { societies and there are so many of them!" (C1) }\end{array}$ & $\begin{array}{l}\mathrm{C} 1, \mathrm{C} 2, \mathrm{C} 3 \\
\mathrm{C} 4, \mathrm{C} 5 \\
\mathrm{C} 1, \mathrm{C} 2, \mathrm{C} 3 \\
\mathrm{C} 4, \mathrm{C} 5\end{array}$ \\
\hline
\end{tabular}


Table 6: Definitions of the Institutional Logics Identified

\begin{tabular}{|l|l|}
\hline \multicolumn{1}{|c|}{$\begin{array}{c}\text { Institutional } \\
\text { Logics }\end{array}$} & \multicolumn{1}{c|}{ Definition } \\
\hline $\begin{array}{l}\text { Sustainability } \\
\text { Logic }\end{array}$ & $\begin{array}{l}\text { Aiming at the Triple Bottom Line - with a balanced attitude towards environmental, social and economic } \\
\text { sustainability }\end{array}$ \\
\hline Financial Logic & $\begin{array}{l}\text { Main focus on profitability, and only concerned with sustainability if it leads to greater sales or reduced costs. } \\
\text { From a customers' perspective, main concern with affordability of purchases }\end{array}$ \\
\hline Time Logic & $\begin{array}{l}\text { Concern regarding extra time needed to engage with particular initiatives e.g. to engage with the planting and } \\
\text { growing of crops for consumption in the Edible Campus initiatives used in FHE1 and FHE5 }\end{array}$ \\
\hline
\end{tabular}

Table 7: Cross-tier analysis of Institutional Pressures and Logics in the UK HE food and catering supply chain

\begin{tabular}{|c|c|c|c|c|}
\hline & \multicolumn{4}{|c|}{ Supply Chain Tier } \\
\hline & Supplier & Focal Universities & Customers (SU) & Student Consumers \\
\hline \multicolumn{5}{|l|}{ Pressures: } \\
\hline Normative & Weak (but exceptions) & Strong & Medium & $\mathrm{n} / \mathrm{a}$ \\
\hline Mimetic & Weak (but exceptions) & Strong & Weak & $\mathrm{n} / \mathrm{a}$ \\
\hline Coercive & Strong & Weak & Weak & $\mathrm{n} / \mathrm{a}$ \\
\hline \multicolumn{5}{|l|}{ Logics: } \\
\hline Sustainability Logic & Weak (but exceptions) & Strong & Strong & Weak (but exceptions) \\
\hline Financial Logic & Very Strong & Medium & Weak & Strong \\
\hline Time Logic & $\mathrm{n} / \mathrm{a}$ & $\mathrm{n} / \mathrm{a}$ & Weak & Strong \\
\hline
\end{tabular}


Table 8: Institutional Complexity - evidence of conflicting institutional logics

\begin{tabular}{|c|c|}
\hline $\begin{array}{l}\text { Institutional Logics } \\
\text { Conflicts (Institutional } \\
\text { Complexity Causes) }\end{array}$ & Sample Quotes \\
\hline $\begin{array}{l}\text { Upstream Supply Chain: } \\
\text { Suppliers' Financial Logic vs } \\
\text { Universities' Sustainability } \\
\text { Logic }\end{array}$ & $\begin{array}{l}\text { "But I think that's difficult when I can't come up with those benefits well enough. I'll give you an example in the case of bottles of water. } \\
\text { One of our objectives is always to eliminate plastic water bottles on this campus, it's a huge challenge because it is difficult to argue the } \\
\text { case with caterers because it's like one of their biggest profit makers. So it's hard when they just automatically turn off and don't want to } \\
\text { know and they don't want to even participate in thoughts or any kind of creative thinking about what we can do to maybe supplement that } \\
\text { income in another way. So it is like playing politics really, influencing people and making them see the benefits of things. (FHE4-I2) } \\
\text { "With all the catering companies that I have worked with, at the end of the day they look after their own pocket and their own company } \\
\text { and all of that". (FHE5-I2) } \\
\text { "And sometimes it can be quite difficult, especially with small artisan producers, they don't have the invoicing structure, they are not quite } \\
\text { as slick as maybe the big companies are, so that can be quite a challenge as well (especially in terms of applying for accreditations), they } \\
\text { might just have hand written invoices". (FHE2-II) }\end{array}$ \\
\hline $\begin{array}{l}\text { Downstream Supply Chain: } \\
\text { Student Union's } \\
\text { Sustainability Logic vs } \\
\text { University's Financial Logic }\end{array}$ & $\begin{array}{l}\text { "Also the challenge is when the budget comes and people, departments or areas don't have money to do something different. So if you } \\
\text { have only paper plates but you wanna go to reusable then you have to think that I have to buy a dishwasher and then I gonna have extra } \\
\text { time to wash and I want to put a system in place that people don't steal the cutlery and dishes. So at the end of the day you calculate the } \\
\text { short term cost of things and not having a full cost. But on the other hand that area has to pay for their waste, so for example if they can } \\
\text { save in the garbage that might offset some of the cost. So a thing like full cost accounting is needed". (C4) } \\
\text { "Another challenge would be obviously to convince the University that this is a core project that they want to invest in and give away that } \\
\text { space, because we want to do it outside the building but it will be still within the University properties".(C5-I2) } \\
\text { "Conflicting priorities on space, although a good compromise has been found. We have got } 100 \text { British native fruit trees on campus right } \\
\text { now, we would like to have } 1000 \text { in } 10 \text { years'time. There is no reason why universities shouldn't be world leaders in showing that actually } \\
\text { the urban design should include edible landscaping within it. People can go and pick the fruit for free, but in the future plan it could be } \\
\text { supplied to the university in 5-10 years' time." (C1) }\end{array}$ \\
\hline $\begin{array}{l}\text { Student Consumers' } \\
\text { Financial Logic vs } \\
\text { University's/Student Union's } \\
\text { Sustainability Logic }\end{array}$ & $\begin{array}{l}\text { "I think the concern for me right now is that students will always come back to the economic argument and say well, I would love to buy } \\
\text { more local and sustainable food but it is more expensive, or I would love to buy more organic food and support organic farms but it is more } \\
\text { expensive. So I think the challenge for the university is actually making the local and sustainable food options that are coming on board } \\
\text { through university catering more affordable". (C1) } \\
\text { "And we also ask questions about [whether customers are] ...prepared to pay a premium for Fairtrade produce and organic produce? The } \\
\text { majority of them say not. So it's a difficult one. I think it is important that we do take on board the green agenda and promote it, but we } \\
\text { also have got to be mindful that people can't afford it. So there is a need to have some alternatives". (FHE4-I2) } \\
\text { "There is a demand for it [fair trade and organic], they want it, but they don't want to pay for it, so you have to say hold on a minute, there } \\
\text { is a cost to it, so it's getting that across and finding a way round it". (FHE2-I2) }\end{array}$ \\
\hline $\begin{array}{l}\text { Student Consumers' Time } \\
\text { Logic vs }\end{array}$ & "So they [the students] can get quite vocal but when it comes down to actually turning that into action, it's quite difficult, they love to \\
\hline
\end{tabular}




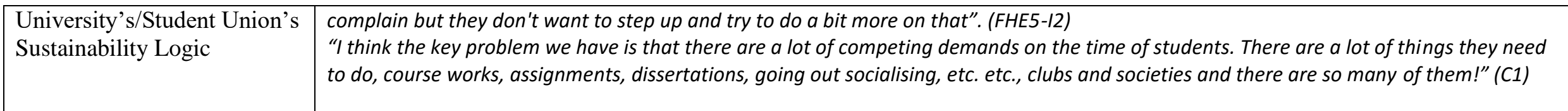


Table A1: Interview questions for the focal organisations, and their links to the main constructs

\begin{tabular}{|c|c|c|c|}
\hline \multirow{2}{*}{ Interview Questions } & \multicolumn{3}{|c|}{ Constructs Measured } \\
\hline & $\begin{array}{c}\text { Institutional } \\
\text { Pressures }\end{array}$ & $\begin{array}{c}\text { Institutional } \\
\text { Logics }\end{array}$ & $\begin{array}{c}\text { Institutional } \\
\text { Complexity }\end{array}$ \\
\hline $\begin{array}{l}\text { Questions for Implementation of Current Sustainability Initiatives: } \\
\text { 1- What are the current sustainability initiatives (environmental \& social initiatives) that } \\
\text { you are implementing in the food and catering procurement section? } \\
\text { 2- Why have these initiatives been selected? } \\
\text { 3- What are the main pressures and drivers behind having a sustainable food and catering } \\
\text { service? } \\
\text { 4- Did you experience any resistance or difficulty from your buyers towards } \\
\text { implementation of these initiatives? If yes, how did you deal with it? } \\
\text { 5- Do you have any principles/guidelines/criteria to use when making difficult decisions on } \\
\text { which supplier to use? (e.g. choosing between a green/expensive supplier and a cheaper } \\
\text { less sustainable alternative)? If not, do you think that some guidelines would be useful? } \\
\text { 6- What is the impact of these sustainable initiatives on financial performance of the } \\
\text { university/procurement department in the short-term/long-term? Would you please give } \\
\text { us some numerical examples? } \\
\text { 7- What are the enablers that help in the implementation of your sustainability agenda? } \\
\text { 8- What are the challenges or barriers that hinder the implementation or success of your } \\
\text { sustainability agenda? } \\
\text { 9- Who are your stakeholders in relation to your procurement function? } \\
\text { 10- Did you experience any pressure from your stakeholders to implement the current } \\
\text { sustainable initiatives including dealing with or selecting sustainable suppliers? And how } \\
\text { did you satisfy your stakeholders by these initiatives? And how do you communicate } \\
\text { these initiatives to your stakeholders? } \\
\text { 11- Have you been offered any kind of incentives or fund from your stakeholders to }\end{array}$ & $\begin{array}{l}\sqrt{ } \\
\sqrt{ }\end{array}$ & $\begin{array}{l}\sqrt{ } \\
\sqrt{ } \\
\sqrt{ }\end{array}$ & $\begin{array}{l}\sqrt{ } \\
\sqrt{ } \\
\sqrt{ } \\
\\
\sqrt{ } \\
\sqrt{ } \\
\sqrt{ }\end{array}$ \\
\hline
\end{tabular}




\begin{tabular}{|c|c|c|c|}
\hline $\begin{array}{l}\text { implement the current sustainable initiatives or to develop your suppliers to be } \\
\text { sustainable? } \\
\text { 12- Are there any governmental regulations or pressures that you try to satisfy or meet by } \\
\text { implementing these current initiatives (e.g., Government Buying Standards (GBS))? } \\
\text { 13- Do you have/plan to have any recognized certification in relation to sustainability } \\
\text { performance (e.g. ISO 14001; Green League Table)? If yes, why do you see it as being } \\
\text { important? If not, why do you think it is not important? } \\
\text { 14- Do you think that the increasing trend for using sustainability initiatives in many areas in } \\
\text { the HE sector has a role for driving you to implement these current sustainable } \\
\text { procurement initiatives? If so, what specific trends have influenced you? } \\
\text { 15- Do you set or plan to set any other organizations as benchmarks for your sustainability } \\
\text { practices? If yes, are they in the HE sector or other sectors and how do you find this } \\
\text { useful? If no, why not? }\end{array}$ & $\sqrt{ }$ & $\begin{array}{l}\sqrt{ } \\
\sqrt{ }\end{array}$ & \\
\hline $\begin{array}{l}\text { Questions for Relationship with suppliers: } \\
\text { 1- Would you please give us an overview about your suppliers (their numbers, categories, } \\
\text { sizes, locations ... etc)? } \\
\text { 2- What is the nature of the contract with the suppliers included in the framework? } \\
\text { 3- How is sustainability being incorporated into selecting your suppliers as well as into } \\
\text { tenders' events? And what are the tools being used in that (e.g. Self-assessment } \\
\text { questionnaire, visiting suppliers' factories, etc)? } \\
\text { 4- How do you define local sourcing practices? And what is the percentage of local } \\
\text { suppliers in your total number of suppliers? } \\
\text { 5- What are the sustainability (environmental, social and economic) and business } \\
\text { advantages of using local suppliers? } \\
\text { 6- What are the challenges of using local suppliers? } \\
\text { 7- What do you think about the total cost of local suppliers (including prices, } \\
\text { transportations ... etc) comparing to other big-national suppliers? } \\
\text { 8- Did you experience any resistance from your suppliers regarding these sustainable }\end{array}$ & $\sqrt{ }$ & $\sqrt{ }$ & $\sqrt{ }$ \\
\hline
\end{tabular}




\begin{tabular}{|l|l|l|}
\hline initiatives? If yes, how did you deal with it? & \\
9- Do you feel a sense of accountability for your suppliers' environmental and social \\
practices? And if yes, why? And how is this accountability extended to multiple tiers \\
across the existing supply chain?
\end{tabular}

